Article

\title{
Options for Sustainable Intensification of Maize Production in Ethiopia
}

\author{
Amit Kumar Srivastava ${ }^{1, * \mathbb{C}}$, Cho Miltin Mboh ${ }^{1}$, Babacar Faye ${ }^{1}$, Thomas Gaiser ${ }^{1}{ }^{\mathbb{D}}$, \\ Arnim Kuhn ${ }^{2}$, Engida Ermias ${ }^{2}$ and Frank Ewert ${ }^{1}$ \\ 1 Institute of Crop Science and Resource Conservation, University of Bonn, Katzenburgweg 5, D-53115 Bonn, \\ Germany; cmboh@uni-bonn.de (C.M.M.); babafaye@uni-bonn.de (B.F.); tgaiser@uni-bonn.de (T.G.); \\ frank.ewert@uni-bonn.de (F.E.) \\ 2 Institute for Food and Resource Economics, University of Bonn, Nussallee 21, D-53115 Bonn, Germany; \\ arnim.kuhn@ilr.uni-bonn.de (A.K.); ermias.engida@ilr.uni-bonn.de (E.E.) \\ * Correspondence: amit.srivastava@uni-bonn.de; Tel.: +49-228-73-2876
}

Received: 23 September 2018; Accepted: 17 March 2019; Published: 21 March 2019

check for updates

\begin{abstract}
The agricultural intensification of farming systems in sub-Saharan Africa is a prerequisite to alleviate rural poverty and to improve livelihood. In this modelling exercise, we identified sustainable intensification scenarios for maize-based cropping systems in Ethiopia. We evaluated Conventional Intensification (CI) as continuous maize monocropping using higher Mineral Fertilizer (MF) rates with and without the incorporation of Crop Residues (CR) in the soil. We also evaluated the effect of groundnut in rotation with the maize-based cropping system with the current Farmer's Practice + Rotation (FP + Rotation) and increased MF application rates (CI + Rotation) combined with CR incorporation. The results suggest that, under CI, there was a positive effect of MF and $\mathrm{CR}$. The incorporation of only CR in the field increased the maize yield by $45.3 \%$ compared to the farmer's yield under current MF rates. CR combined with higher MF $\left(60 \mathrm{~kg} \mathrm{~N} \mathrm{ha}^{-1}+20 \mathrm{~kg} \mathrm{P} \mathrm{ha}^{-1}\right)$ increased the yield by $134.6 \%$. Incorporating $C R$ and MF was also beneficial under rotation with groundnut. The maize yields increased up to $110.1 \%$ depending upon the scenarios tested. In the scenario where $\mathrm{CR}$ was not incorporated in the field, the maize yield declined by $21.9 \%$. The Gross Economic Profit suggests that groundnut in rotation with maize is advantageous across Ethiopia in terms of the net return with a few exceptions.
\end{abstract}

Keywords: sustainability; intensification options; maize; groundnut; crop residue; crop model

\section{Introduction}

Sub-Saharan Africa (SSA) is the region at greatest food security risk because, by 2050, its population is likely to increase 2.5-fold and the demand for cereals will approximately be tripled [1]. Also noted is that SSA's self-sufficiency (a ratio between domestic production and total consumption or demand) in staple cereals is among the lowest compared to other subcontinents, indicating the current levels of cereal consumption already depend on substantial imports.

The main reasons for the low self-sufficiency include soil nutrient depletion, soil erosion, and erratic or low precipitation [2]. The prevailing practice of low-input agriculture is not only providing little outputs but also detrimental to soils [3]. These issues, combined with continuous cereal-based cropping systems without sufficient nutrient inputs to the soil, have led to large-scale declines in soil fertility and persistently poor crop yields on smallholder farms [4]. The challenge of meeting the demands of a growing population can be met by bringing new land into cultivation [5] but that is not a sustainable solution, as often the suitable lands are already in use [6] and land naturally is a limited resource. Nitrogen $(\mathrm{N})$, as one of the most limiting nutrients in agriculture, is a key 
component in the proper functioning of cropping systems. However, a dependence on synthetic $\mathrm{N}$ fertilizers has adverse economic and environmental consequences, such as the nitrate pollution of groundwater, the atmospheric pollution from ammonia, and a contribution to global warming due to nitrous oxide emissions [7]. There are situations in arable systems where the introduction of legumes has both economic and environmental advantages, especially when grain legumes achieve high prices as human food. Grain legumes fix atmospheric nitrogen gas $\left(\mathrm{N}_{2}\right)$ and can contribute to the $\mathrm{N}$ economy of fields, provide other rotational benefits to subsequent crops, produce in situ high-quality organic residues with a high $\mathrm{N}$ concentration and a low $\mathrm{C}$ to $\mathrm{N}$ ratio, and thereby contribute to integrated soil fertility management [8]. Moreover, ecosystem services, including reduced nitrous oxide emissions and nitrate leaching and increased biodiversity, are currently not awarded through payments, so they are not considered in a farmer's economic calculations. Farmers seldom consider the long-term benefits, focusing instead on single years. This leads to an underestimation of the services provided by legumes. The valuation of such services requires an assessment at the cropping-system scale [9].

To meet the increasing food demands in SSA and to protect the environmental quality simultaneously in a sustainable manner, it is necessary to optimize agronomic management practices to enhance the nitrogen and water use efficiency [10]. Quantifying the rotational effect of grain legumes on subsequent crops is important for understanding the adoption potential of legume technologies as well as their impact on the sustainability of production [11].

Various approaches have been proposed to overcome soil nutrient limitations such as (i) conventional intensification mainly based on the increased use of mineral fertilizer [12], (ii) using legumes in rotation with the main crop or intercropping systems [3], or (iii) a mix of both by rotation with legumes and supplementary mineral $\mathrm{N}$ supply [13]. The mixed approach is widely being promoted in agricultural development programs for small-scale farming in SSA [14], while conventional intensification is the approach mostly taken currently in large-scale farming [2]. We are unaware of any recent studies in Ethiopia that synthesize the effect of legumes in rotation with the main crop evaluating the options of sustainable intensification.

Therefore, here, we use a biophysical modelling framework combined with a cost-benefit analysis to identify sustainable intensification scenarios for maize-based cropping systems in Ethiopia through investigating (i) the long-term crop yield response and (ii) the change in crop available $\mathrm{N}$ and organic carbon over time.

\section{Materials and Methods}

\subsection{Study Area and Simulation Units}

Ethiopia lies within the tropics between $3^{\circ} 24^{\prime}$ and $14^{\circ} 53^{\prime} \mathrm{N}$ and $32^{\circ} 42^{\prime}$ and $48^{\circ} 12^{\prime}$ E with an estimated arable land area of 15.1 million hectares [15]. The climate of the country is diverse, ranging from semiarid desert in the lowlands to humid and warm (temperate) in the southwest. The mean annual rainfall distribution ranges from a maximum of more than $2000 \mathrm{~mm}$ over the Southwestern highlands to a minimum of less than $300 \mathrm{~mm}$ over the Southeastern and Northwestern lowlands. The mean annual temperature also varies widely, from lower than $15^{\circ} \mathrm{C}$ over the highlands to above $25^{\circ} \mathrm{C}$ in the lowlands [16]. The simulations were done at the $1 \mathrm{~km}$ grid cell level, where cropland (Figure 1) and soil data are available (details about soil data is under Section 2.6.1). The long maturing cycle maize variety (see details in Section 2.3) was used in the simulations in Agroecological Zones (AEZs) 1 and 2 (Figure 1) where the length of major crop growing season is more than 160 days, elsewhere (AEZ 3) a medium maturing cycle variety was used in the simulations. The simulated yield from all the simulation units over 7 years (2004-2010) within each administrative zone was averaged to obtain a representative value for a specific year to compare them with the observed yield. 


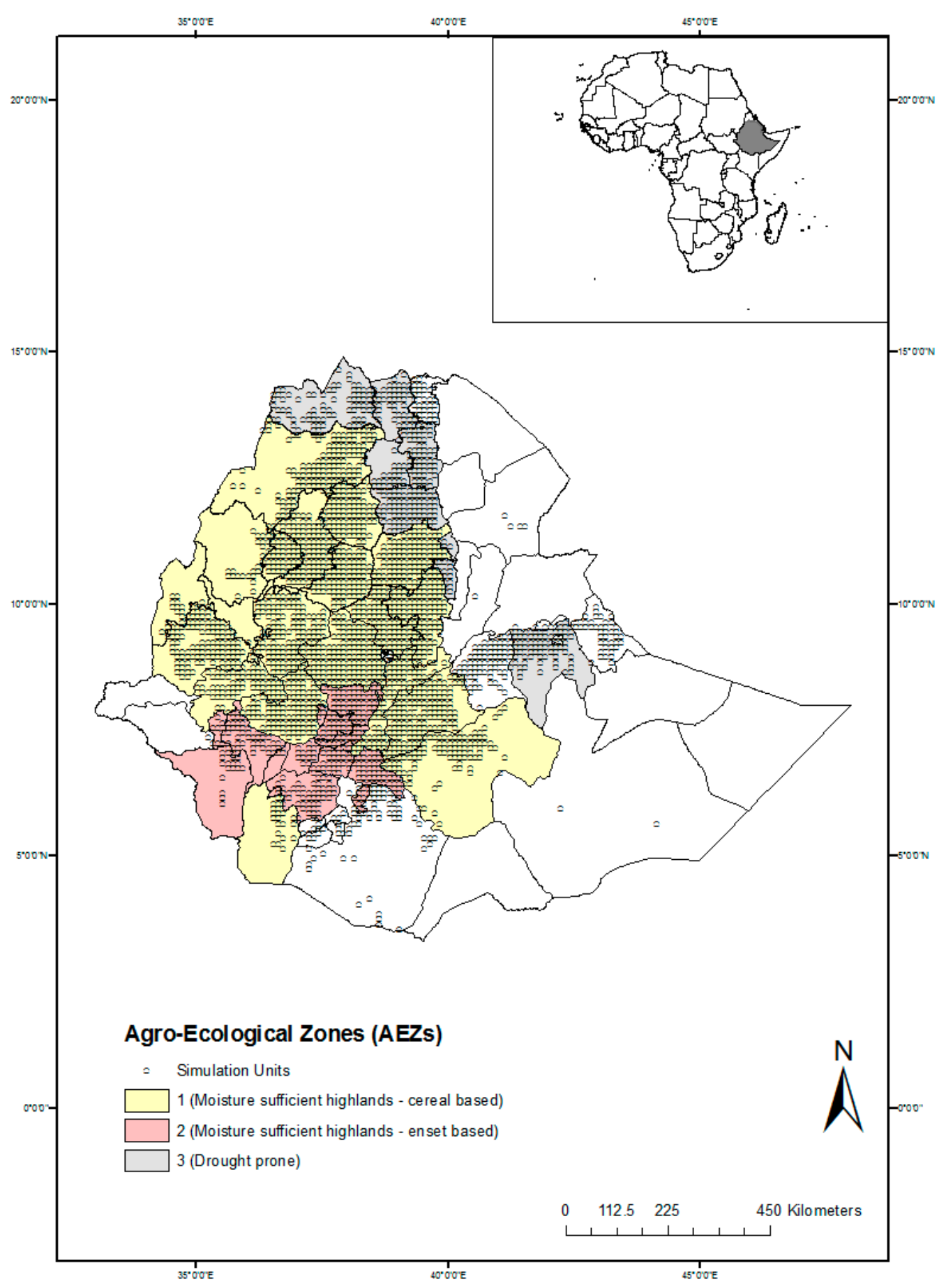

Figure 1. A map of Ethiopia showing the simulation units and the Agroecological zones.

\subsection{Model Setup and Description}

LINTUL5 is a biophysical model that simulates plant growth, biomass, and yield as a function of climate, soil properties, and crop management using experimentally derived algorithms. LINTUL 5 has been widely used in various studies at the field, country, and continental scale [17-20]. Additionally, the crop model used in the current study has been used in earlier studies, showing its ability to simulate the growth and development of Groundnut (variety "Fleur11") [21] and the crops in rotations [22,23]. The effect of legume crops on the subsequent crops in the rotation is simulated as a fraction of the crop $\mathrm{N}$ uptake by biological fixation which was fixed as a parameter in the crop parameter file [21]. 
The applied version of LINTUL5 simulates the potential crop growth (limited by solar radiation only) under well-watered conditions; ample nutrient supply; and the absence of pests, diseases, and weeds [24]. Biomass production is based on intercepted radiation according to Lambert-Beer's law and light use efficiency. The produced biomass is partitioned among various crop organs (leaves, stems, storage organs, and roots) according to the partitioning coefficients defined as a function of the development stage of the crop. The phenology is simulated by the accumulation of thermal time above a defined base temperature. Photosynthesis and the total crop growth rate are calculated by multiplying the intercepted light and radiation use efficiency (RUE). The total crop growth, root-shoot partitioning, and leaf area expansion are further influenced by water stress. Water stress occurs when the available soil water is between a defined critical point and a wilting point or higher than the field capacity (water-logging). The critical point is a crop specific value which is calculated according to Reference [25] and depends on crop development, soil water tension, and potential transpiration. Water, nutrients (NPK), temperature, and radiation stresses restrict the daily accumulation of biomass, root growth, and yield. The stress indices are calculated daily for the water and nutrient limitations and range from 0.0 to 1.0. The estimation of the daily increase in crop biomass considers, on a given day, the maximum stress index among water, nitrogen, phosphorus, and potassium stress. Water stress occurs when available water in the soil is below the crop-water demand. The same holds for nitrogen stress, that is, when the crop available nitrogen in the rooted soil profile is lower than crop nitrogen demand. To simulate a continuous cropping system, the model was embedded into a general modeling framework, SIMPLACE (Scientific Impact Assessment and Modelling Platform for Advanced Crop and Ecosystem Management) [22]. The SIMPLACE<LINTUL5-SLIM-SoilCN> solution of the modeling platform was used in this study. SLIM is a conceptual soil water balance model subdividing the soil in a variable number of layers, substituting the two-layer approach in Lintul5. The crop residue effect on the crop yield was implemented in the crop model. Before the harvest of annual crops, some crop parameters define the death rate of roots and the start of the root senescence. The dead roots are transferred to the so-called "root litter pool" in the SoilCN SimComponent. At harvest, after removing the marketable part of the crop (in this case grains of legume and maize), the above and below ground residues are rooted into the respective litter pools of the SoilCN SimComponent. In both cases, carbon in the residues are routed into the carbon fraction for the respective litter pool and the amount of $\mathrm{N}$ in the residues is routed into the nitrogen fraction of the respective litter pool. The decomposition, mineralization, and humification of the litter pools in each soil layer are mainly triggered by the soil moisture, soil temperature, clay content, and maximum decomposition rates as shown in Reference [26]. The effect of crop residue retention on the crop is mainly through the maintenance of a certain soil organic nitrogen content and subsequently higher average mineral nitrogen concentrations in the soil, thus improving average $\mathrm{N}$ supply to the crop.

\subsection{Dataset for Maize Model Calibration}

In this study, two sets of hybrid maize cultivar-related parameters, namely BH660 (a long maturing cycle variety) and BH540 (a medium maturing cycle variety), (Table 1) were calibrated against the experimental data (yield and phenology) under rain-fed conditions collected from the Melko (Jimma Agricultural Research Centre), located on $7^{\circ} 39^{\prime} 56.4^{\prime \prime}$ latitude north and $36^{\circ} 46^{\prime} 56.4^{\prime \prime}$ longitude east in Ethiopia for the years 2008 to 2012. The fertilizer application rate used in the experiments was $23 \mathrm{~kg} \mathrm{ha}^{-1}$ of urea and $217 \mathrm{~kg} \mathrm{ha}^{-1}$ DAP (Di-Ammonium Phosphate) at planting and $150 \mathrm{~kg} \mathrm{ha}^{-1}$ urea after 35 days of planting. According to Reference [27], both BH660 and BH540 are the most popular and widely grown maize varieties in the country, covering major maize producing areas. The Maize (Z. mays) crop parameter dataset (provided with the LINTUL5 model and Reference [17]) was used as a starting point to establish a new parameter set for these maize varieties. 


\subsection{Dataset for Groundnut Model Calibration}

The field experiments were conducted in Bambey located at $14^{\circ} 42^{\prime} \mathrm{N}$ and $16^{\circ} 29^{\prime} \mathrm{W}$ and in Nioro located at $13^{\circ} 45^{\prime} \mathrm{N}$ and $15^{\circ} 46^{\prime} \mathrm{N}$ in Senegal during the dry and rainy seasons of 2014 and dry season of 2015 [28]. The peanut cultivar selected was Fleur11, known to be an early (90 days) maturity cultivar. Phenology observations were taken approximately every seven days to determine the parameters such as the day of emergence, the day of flowering, the beginning of peg, the beginning of pod formation, the beginning of seed, and physiological maturity as described in References [29,30]. The total dry matter was determined in leaves, stems, and pods on a weekly basis. At final harvest, the biomass and seed yield were determined in each plot in an area of $3.9 \mathrm{~m}^{2}(1.95 \mathrm{~m} \times 2 \mathrm{~m})$. Most of the parameters used in the Lintul5 model are default values reported in Reference [24]. However, as no published studies exist with LINTUL5 for peanut or other legumes, some parameters values were adjusted based on the literature and from field measurements. Some parameter values were manually adjusted during the calibration process in order to adapt them to local conditions. The parameters of the model are given in Table 1.

\subsection{Statistical Tools Used}

As a measure of accuracy to compare the statistical data and simulated values, the following objective functions were used [31]:

a. The mean relative error $(M R)$ as

$$
M R=\frac{1}{n} \sum_{i=1}^{n} \frac{\left(y_{i}-x_{i}\right)}{x_{i}}
$$

b. The mean residual error $(M E)$ as

$$
M E=\frac{1}{n} \sum_{i=1}^{n} y_{i}-x_{i}
$$

where $n$ is the sample number, $x$ is the observed, and $y$ is the simulated value. A value of 0 for $M E$ indicates no systematic bias between the simulated and measured values. The $M R$ gives an indication of the mean magnitude of the error in relation to the observed value. Small values indicate little difference between the simulated and measured values.

c. Root mean square error (RMSE) as

$$
R M S E=\sqrt{\frac{1}{n} \sum_{i=1}^{n}\left(s_{i}-o_{i}\right)^{2}}
$$

where $S_{i}$ is the simulated yield, $O_{i}$ is the observed yield, and $\mathrm{n}$ is the total number of observations.

The daily climatic data were recorded at the meteorological stations of Jimma situated at 1718 meters above sea level and provided by the National Meteorological Agency (NMA) of Ethiopia. The required soil data for the crop model were provided by the National Soil Testing Center of Ethiopia (Table A2 in Appendix A). 
Table 1. The crop parameters of LINTUL5 used in the study of maize (varieties BH660 and BH540) and Groundnut (variety Fleur11).

\begin{tabular}{|c|c|c|c|c|}
\hline \multirow{2}{*}{ Name } & \multirow[t]{2}{*}{ Description } & \multirow[t]{2}{*}{ Unit } & \multirow{2}{*}{$\begin{array}{c}\begin{array}{c}\text { Value for } \\
\text { Maize Varieties }\end{array} \\
\text { BH660/ BH540 }\end{array}$} & \multirow{2}{*}{$\begin{array}{c}\begin{array}{c}\text { Value for } \\
\text { Groundnut Variety }\end{array} \\
\text { Fleur } 11\end{array}$} \\
\hline & & & & \\
\hline \multicolumn{5}{|c|}{ Crop parameters } \\
\hline TSUM1 & Temperature sum from emergence to anthesis & ${ }^{\circ} \mathrm{C}$ day-1 & $1000 / 680$ & 422 \\
\hline TSUM2 & Temperature sum from anthesis to maturity & ${ }^{\circ} \mathrm{C}$ day- 1 & $990 / 760$ & 1285 \\
\hline TBASEM & Lower threshold temperature for emergence & ${ }^{\circ} \mathrm{C}$ & 8.0 & 10.0 \\
\hline TEFFMX & Maximum effective temperature for emergence & ${ }^{\circ} \mathrm{C}$ & 30.0 & 30.0 \\
\hline TSUMEM & Temperature sum from sowing to emergence & ${ }^{\circ} \mathrm{C}$ & 56.0 & 25.0 \\
\hline RUE-0.0 & Radiation use efficiency at development stage 0 & g MJ-1 & 3.2 & 2.6 \\
\hline RUE-1.0 & Radiation use efficiency at development stage 1.0 & g MJ-1 & 2.5 & 2.6 \\
\hline RUE-1.50 & Radiation use efficiency at development stage 1.50 & g MJ-1 & 2.2 & 2.4 \\
\hline RUE-2.0 & Radiation use efficiency at development stage 2.0 & g MJ-1 & 2.0 & 2.0 \\
\hline SLATB- 0.0 & Specific leaf area at development stage 0 & $\mathrm{~m} 2 \mathrm{~g}-1$ & 0.03 & 0.022 \\
\hline SLATB-1.0 & Specific leaf area at development stage 1.0 & $\mathrm{~m} 2 \mathrm{~g}-1$ & 0.02 & 0.021 \\
\hline SLATB-2.0 & Specific leaf area at development stage 2.0 & $\mathrm{~m} 2 \mathrm{~g}-1$ & 0.02 & 0.018 \\
\hline LAI critical & $\begin{array}{l}\text { Critical leaf area beyond which leaves die due } \\
\text { to self shading }\end{array}$ & $\mathrm{m} 2 \mathrm{~m}-2$ & 4.0 & 4.0 \\
\hline RGRLAI & Maximum relative increase in LAI & ha ha-1 day-1 & 0.02 & 0.018 \\
\hline ROOTDI & Initial rooting depth & $\mathrm{m}$ & 0.1 & 0.1 \\
\hline ROOTDM & Maximum rooting depth & $\mathrm{m}$ & 2.0 & 0.6 \\
\hline RRDMAX & Maximum rate of increase in rooting depth & $\mathrm{m}$ & 0.012 & 0.012 \\
\hline TDWI & Initial total crop dry weight & $\mathrm{kg}$ ha-1 & 5.0 & 6.0 \\
\hline
\end{tabular}

\subsection{Datasets Used at the National Level}

\subsubsection{Climate and Soil Data}

The climate data at the national scale was made available from the National Aeronautics and Space Administration (NASA), Goddard Institute of Space Studies (https: / / data.giss.nasa.gov /impacts / agmipcf/agmerra/), AgMERRA [32] and consists of the daily time series over the 1980-2010 period with a global coverage of the climate variables required for agricultural models (i.e., the minimum and maximum temperature, solar radiation, precipitation, and windspeed). These datasets are produced by combining state-of-the-art reanalyses (NASA's Modern-Era Retrospective analysis for Research and Applications, MERRA [33] and NCEP's Climate Forecast System Reanalysis, CFSR [34], with observational datasets from in situ observational networks and satellites. The dataset is stored at $0.25^{\circ} \times 0.25^{\circ}$ horizontal resolution (approx. $25 \mathrm{~km}$ ). The values for relevant soil parameters for each soil layer down to the maximum soil depth (sand, clay, bulk density, Soil available water, and organic carbon) were extracted from the soil property maps of Africa at a $1 \mathrm{~km} \times 1 \mathrm{~km}$ resolution (http:/ / www.isric.org/data/ soil-property-maps-africa-1-km) (Figure 2). Other parameters such as soil water at field capacity, wilting point and saturation point, and the Van-Genuchten parameters were computed [35]. These soil parameter values were used as an input to the soil water balance module of the crop model used in simulations at a regional scale (Figure 2).

\subsubsection{Crop Yield and Fertilizer Application Data}

The Maize and Groundnut yields $\left(\mathrm{Mg} \mathrm{ha}^{-1}\right)$ and fertilizer application (Nitrogen and Phosphorus) rates in maize over seven years (2004-2010) at the administrative zone level have been collected from the Central Statistical Agency, Ethiopia. These values have been averaged over cropland and used for the model calibration at the national scale. However, no fertilizer was applied in the Groundnut simulations. 


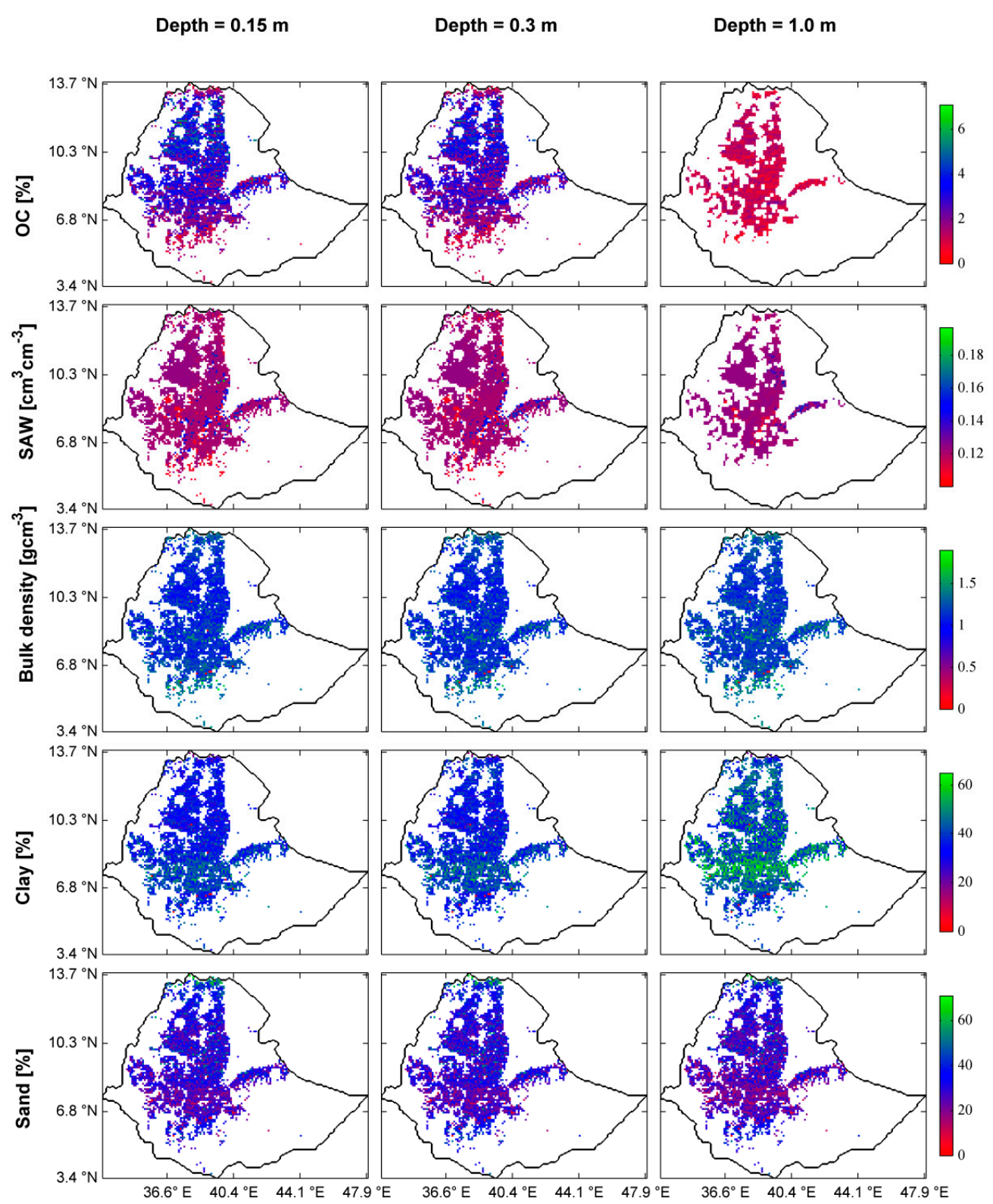

Figure 2. The soil physical properties (sand, clay, bulk density, soil available water (SAW), and soil organic carbon (OC) at three soil depths (i.e., $0.15,0.3$, and $1.0 \mathrm{~m}$ ) of Ethiopia covering the cropland.

\subsection{Intensification Scenarios}

Groundnuts are also a source of cash income in Ethiopia that contribute significantly to food security and alleviate poverty [36]. As a legume, groundnuts improve soil fertility by fixing nitrogen and thereby increasing the productivity of the semiarid cereal cropping systems [37]. Therefore, we are exploring different crop management scenarios (Table 2) in the maize production system by using supplementary a mineral fertilizer supply, by recycling crop residues, and by rotating with $\mathrm{N}$ fixing Groundnuts. For the simulation of the intensification scenarios, the simulation period was 7 years with a preceding spin-up phase of 7 years to make sure that the soil organic matter pools of the model solution were approximating the equilibrium level of the respective treatment. 
Table 2. The crop management scenarios for Maize production explored in Ethiopia.

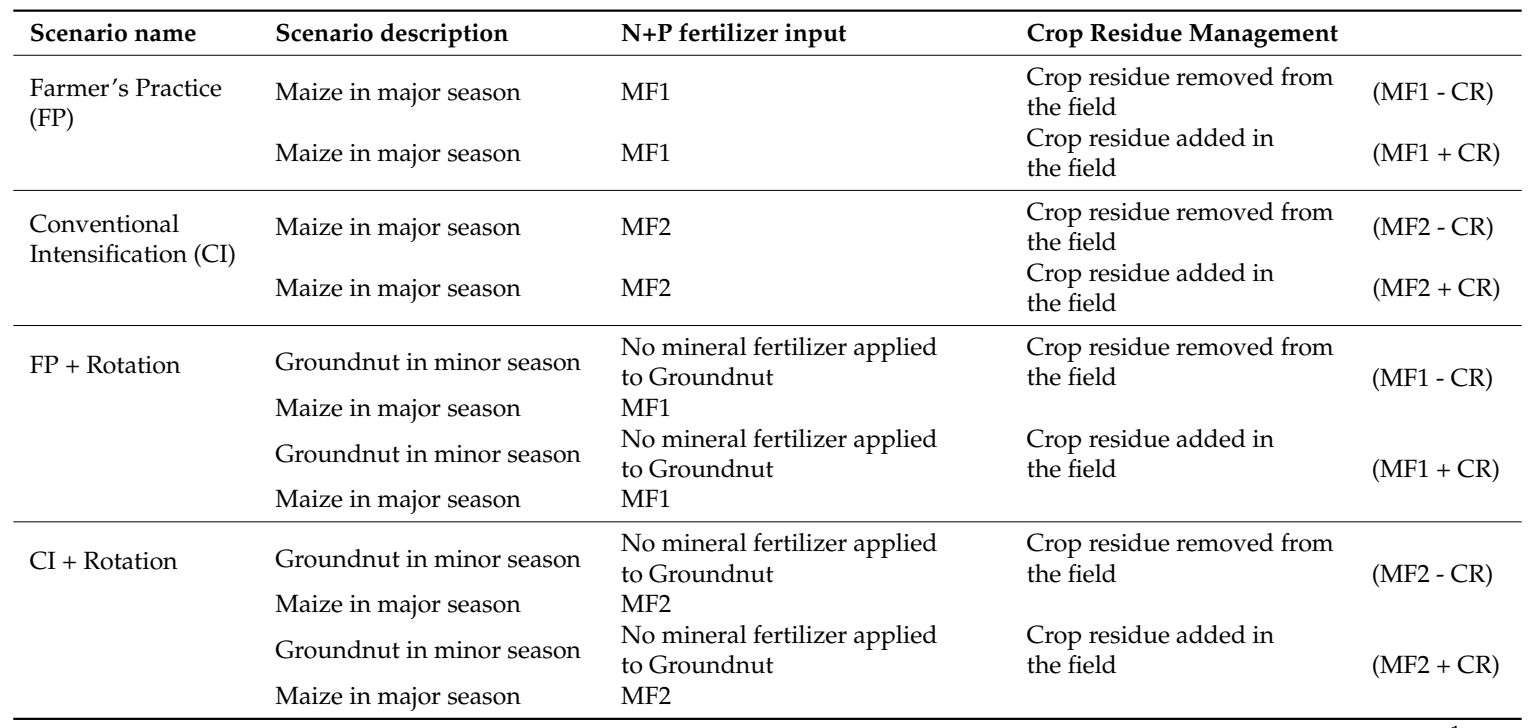

where FP = Farmer's Practice; CI = Conventional Intensification; MF1 = current fertilizer rates; $\mathrm{MF} 2=60 \mathrm{~kg} \mathrm{~N} \mathrm{ha}{ }^{-1}$

$+20 \mathrm{~kg} \mathrm{P} \mathrm{ha}^{-1} ; \mathrm{CR}=$ Crop Residue.

\section{Results}

\subsection{Model Calibration and Evaluation}

The observed and simulated days of maturity under the fertilized production treatment agreed well. In the case of variety BH660, the model overestimated the Day of Maturity (DOM) by one day compared with the observed value, whereas for variety BH540, the observed and simulated DOM matched exactly (Table 3). The model overestimated the day of anthesis by 4 days for both the maize varieties (Table 3). The simulated average grain yield of both the maize varieties was comparable to the corresponding observations where the model overestimated the grain yield of variety BH660 by $4 \%$ and underestimated the grain yield of variety $\mathrm{BH} 540$ by $-1.6 \%$ (Table 3 ), whereas plotting all the observation points of variety BH660 (n = 3) and BH540 (n =5) with the corresponding simulated values resulted in high root mean square values (RMSE) (Figure 3). When applied at the 35 administrative zones in Ethiopia, the average simulated yields of the districts were in the range of the observed yields averaged over 7 years (Figure 4) with an RMSE of $0.64 \mathrm{Mg} \mathrm{ha}^{-1}$. However, the RMSE varied from $0.4 \mathrm{Mg} \mathrm{ha}^{-1}$ to $1.4 \mathrm{Mg} \mathrm{ha}^{-1}$ across the administrative zones where all the observed yield values were plotted against the simulated values for 7 years (2004-2010) (Figure 5).

The discrepancy observed in the simulated yield could have been due to the soil parameters used from the ISRIC (International Soil Reference and Information Centre) database, which refer to soil samples that are representative of large areas. Available soil data does not likely represent long-term cultivated, nutrient-depleted soils. Regarding Groundnut, at both test sites, the model underestimated the day of anthesis by 1 day (Table 3), whereas the day of maturity was overestimated by 1 day at Niaro and at Bambey; the simulated day of maturity matched the observed (Table 3). The average simulated grain yield at both sites was overestimated by $14.4 \%$ and $15 \%$ respectively (Table 3 ), whereas plotting all the observation points in Niaro $(n=3)$ and Bambey $(n=3)$ with the corresponding simulated values resulted in a higher variability and higher root mean square values (RMSE) (Figure 3). When applied at the 10 administrative zones in Ethiopia, the average simulated yields of the districts were in the range of the observed yields averaged over 7 years (Figure 6) with a root mean square error (RMSE) of $0.29 \mathrm{Mg} \mathrm{ha}{ }^{-1}$, whereas the RMSE varied from $0.97 \mathrm{Mg} \mathrm{ha}^{-1}$ to $0.40 \mathrm{Mg} \mathrm{ha}^{-1}$ across the administrative zones when all the observed yield values were plotted against the simulated yield values (Figure 7). 
Table 3. The observed and simulated Grain yield, Day of Anthesis (DOA), Day of Maturity (DOM), mean residual error (ME), and mean absolute error (MR) for the maize variety BH660 and BH540 at Jimma in Ethiopia and for the Groundnut (variety Fleur11) at Nioro and Bambey in Senegal.

\begin{tabular}{|c|c|c|c|c|c|c|c|c|c|c|}
\hline Variety & Site & Treatment & DOA & DOA & DOM & DOM & Grain Yield & Grain Yield & ME & MR \\
\hline & & & Observed & Simulated & Observed & Simulated & $\begin{array}{l}\text { Observed } \\
\text { (Mg ha-1) }\end{array}$ & $\begin{array}{l}\text { Simulated } \\
\text { (Mg ha-1) }\end{array}$ & $\begin{array}{c}\text { Grain Yield } \\
\text { (Mg ha-1) }\end{array}$ & $\begin{array}{c}\text { Grain Yield } \\
(\%)\end{array}$ \\
\hline BH660 & Jimma & Fertilized & 70 & 74 & 160 & 161 & 10.0 & 10.4 & 0.4 & 4.0 \\
\hline BH540 & Jimma & Fertilized & 71 & 75 & 150 & 150 & 6.2 & 6.1 & -0.1 & -1.6 \\
\hline Fleur11 & Niaro & $\begin{array}{l}\text { Without } \\
\text { fertilizer }\end{array}$ & 102 & 101 & 166 & 167 & 2.03 & 2.28 & 0.25 & 14.4 \\
\hline Fleur11 & Bambey & $\begin{array}{l}\text { Without } \\
\text { fertilizer }\end{array}$ & 110 & 109 & 175 & 175 & 1.81 & 2.14 & 0.32 & 15.0 \\
\hline
\end{tabular}
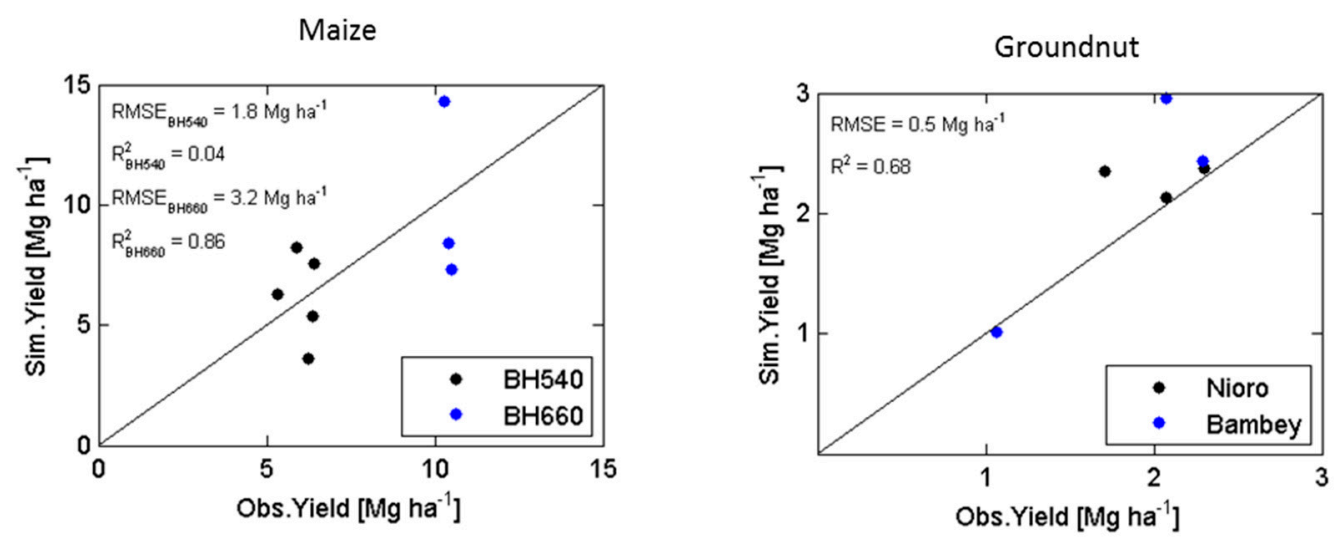

Figure 3. A 1:1 plot of the simulated (water and nutrient-limited) and observed (farmer's yield) two varieties of maize (BH540 $\mathrm{n}=5$ and BH660 $\mathrm{n}=3$ ) and groundnut variety "Fleur11" at two sites Nioro $(n=3)$ and Bambey $(n=3)$. RMSE = Root Mean Square Error and $R^{2}=$ Coefficient of Determination.

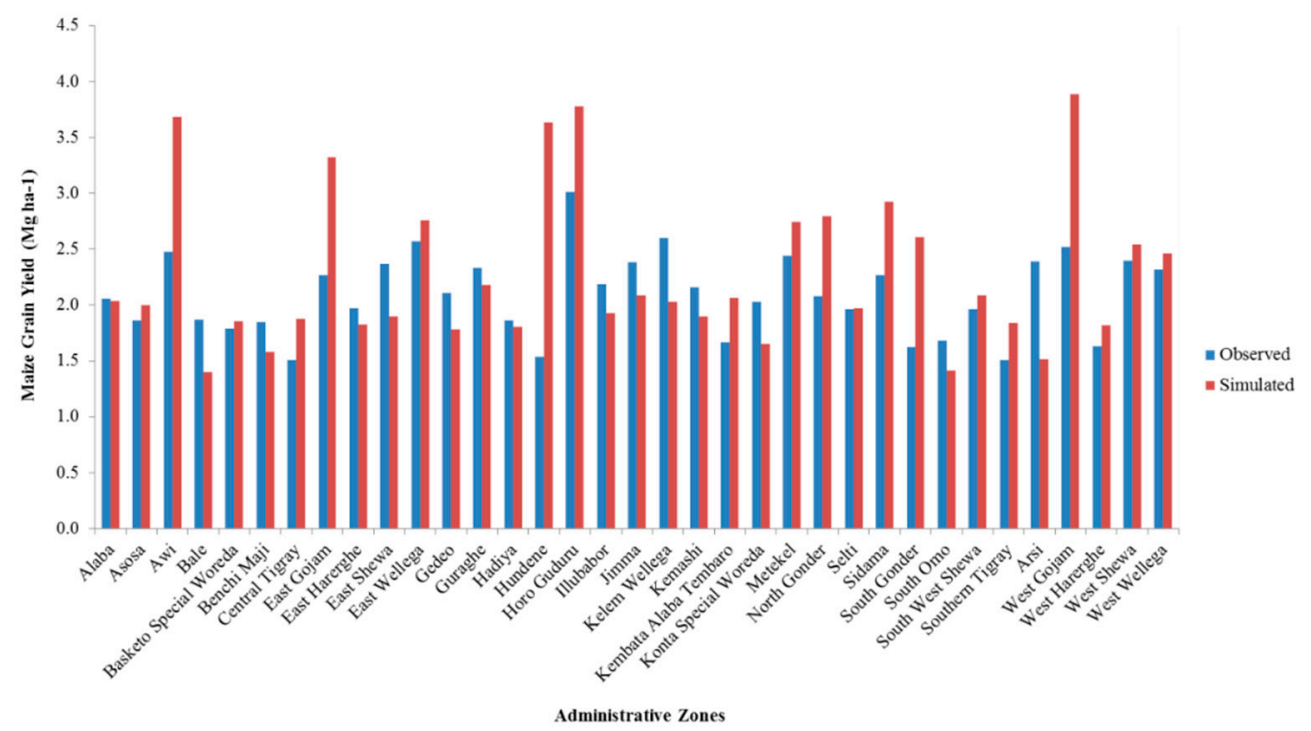

Figure 4. The simulated (water and nutrient-limited) versus observed (farmer's yield) maize yield averaged over 7 years (2004-2010) across 35 administrative zones in Ethiopia with Root Mean Square Error $(\mathrm{RMSE})=0.64 \mathrm{Mg} \mathrm{ha}^{-1}$. 

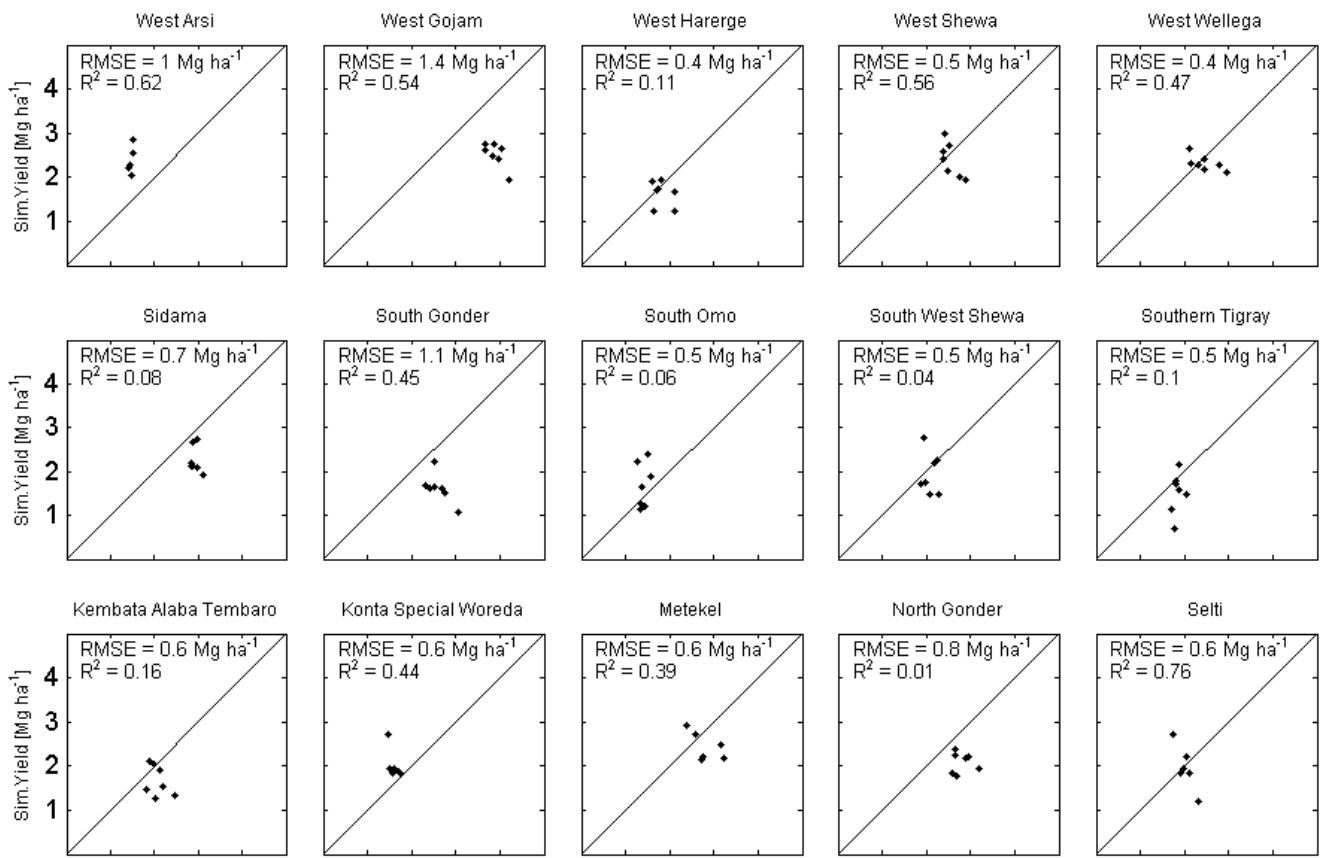

Konta Special imioreda
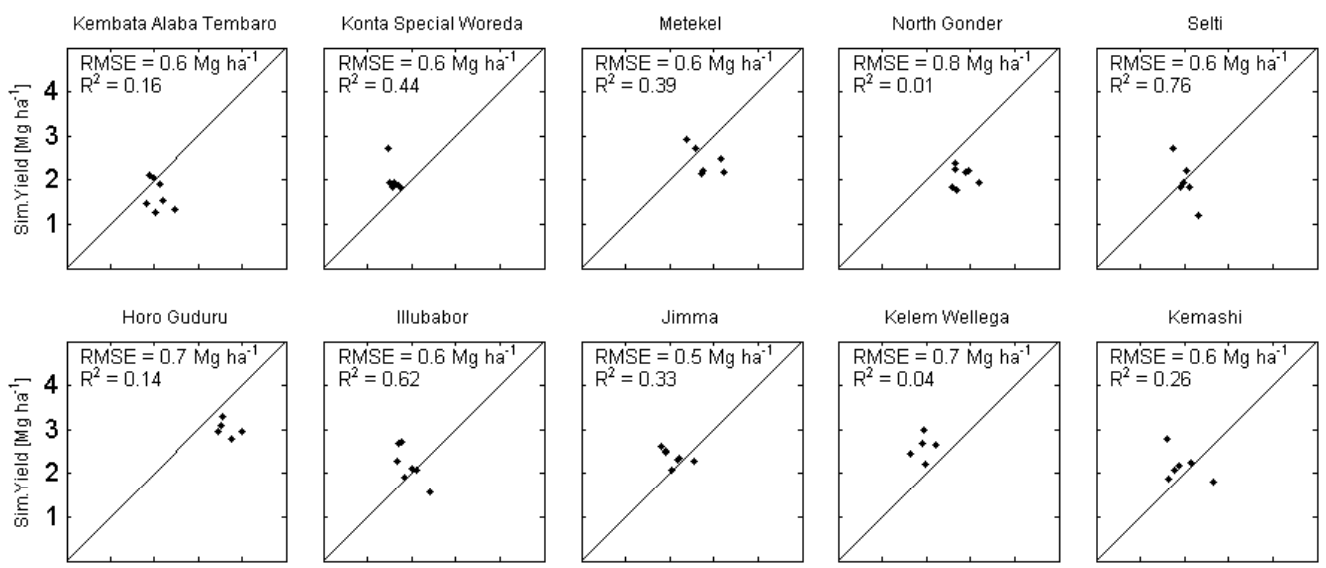

Kelem Wellega

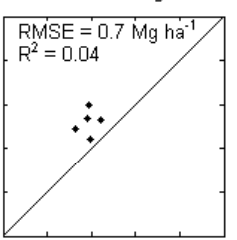

Kemashi
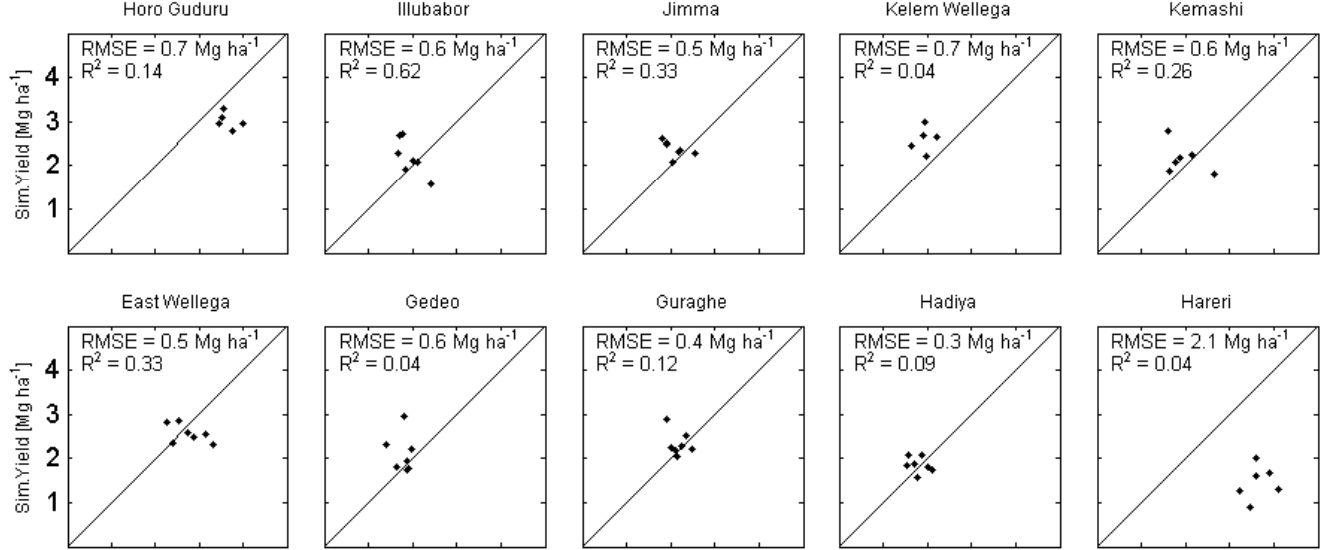

Guraghe

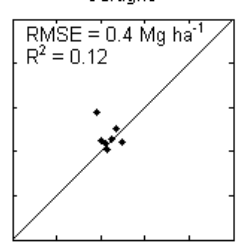

Hadiya

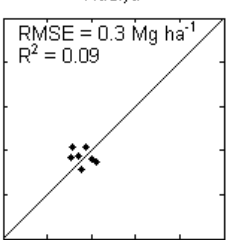

Hareri
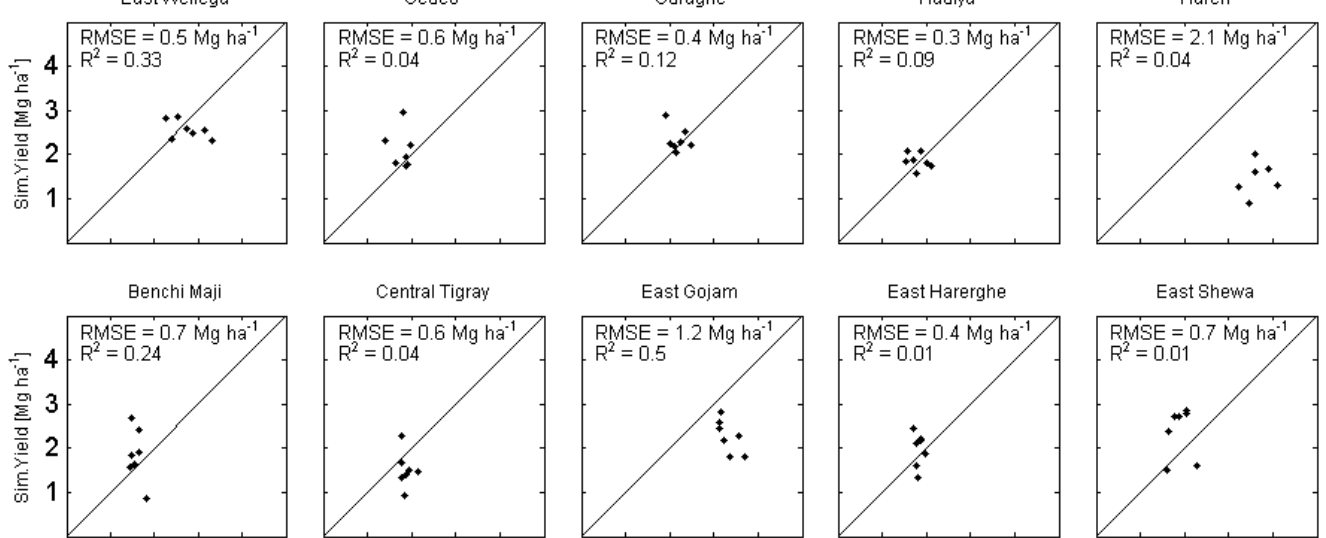

East Gojam
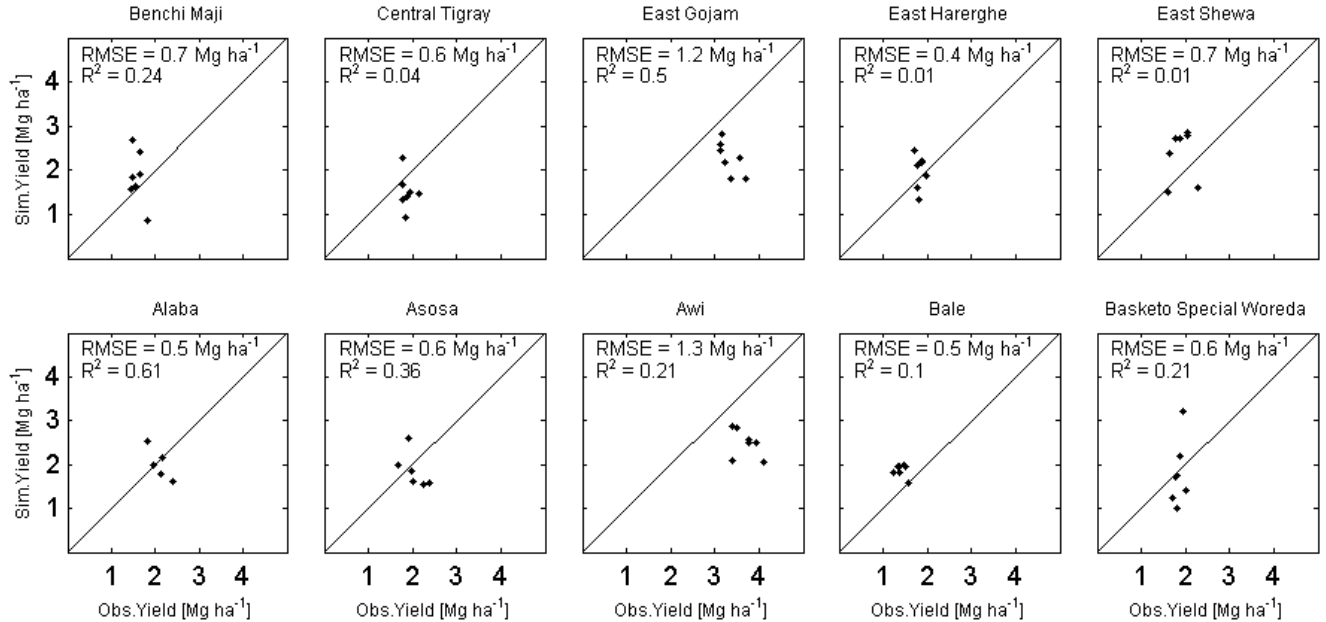

Figure 5. The simulated (water and nutrient-limited) versus observed (farmer's yield) maize yield across 35 administrative zones in Ethiopia across the 7 years (2004-2010) with the Root Mean Square Error (RMSE) and Coefficient of Determination $\left(R^{2}\right)$. 


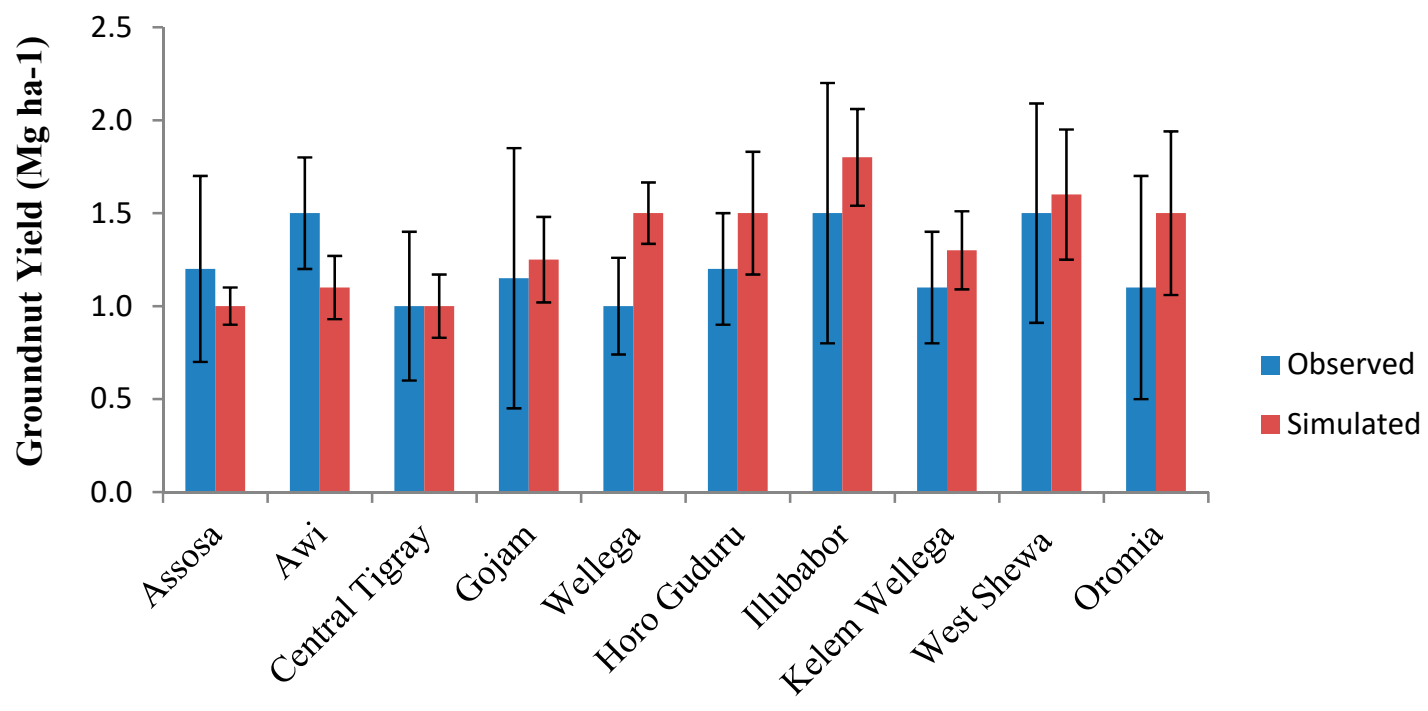

\section{Administrative Zones}

Figure 6. The simulated (water and nutrient-limited) versus observed (farmer's yield) groundnut yield averaged over 7 years (2004-2010) across 10 administrative zones in Ethiopia with Root Mean Square Error $(\mathrm{RMSE})=0.29 \mathrm{Mg} \mathrm{ha}^{-1}$.
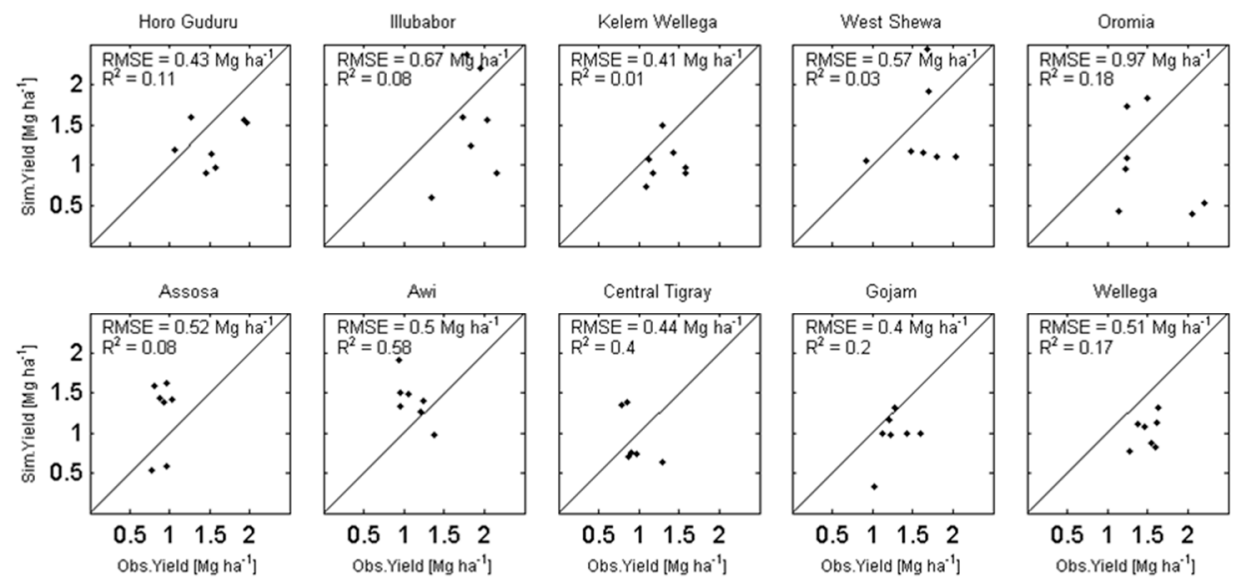

Figure 7. The simulated (water and nutrient-limited) versus observed (farmer's yield) groundnut yield across 10 administrative zones in Ethiopia with the Root Mean Square Error (RMSE) and Coefficient of Determination $\left(R^{2}\right)$ values.

\subsection{Effects of Integrating Crop Residue and Mineral Fertilizer into the Cropping System}

Under the conventional intensification options explored in the current study, the simulation results show the positive effect of mineral fertilizer application and incorporation of the crop residue into the soil. The incorporation of only the crop residue in the field can lead to an increase in the maize yield by $45.3 \%$ compared to the farmer's yield under current mineral fertilizer application rates, whereas the crop residues combined with an increased amount of mineral fertilizer resulted in an increased yield of about $134.6 \%$ (Figure 8).

The effect of incorporating crop residues in combination with mineral fertilizer was also beneficial under the option where maize was grown in rotation with Groundnut (CI + rotation). The yields were increased up to $110.1 \%$ depending upon the scenarios tested (Figure 8). However, in the scenario where crop residues were not incorporated in the field (FP + rotation-CR), the maize yield was reduced by $21.9 \%$ (Figure 8 ). 


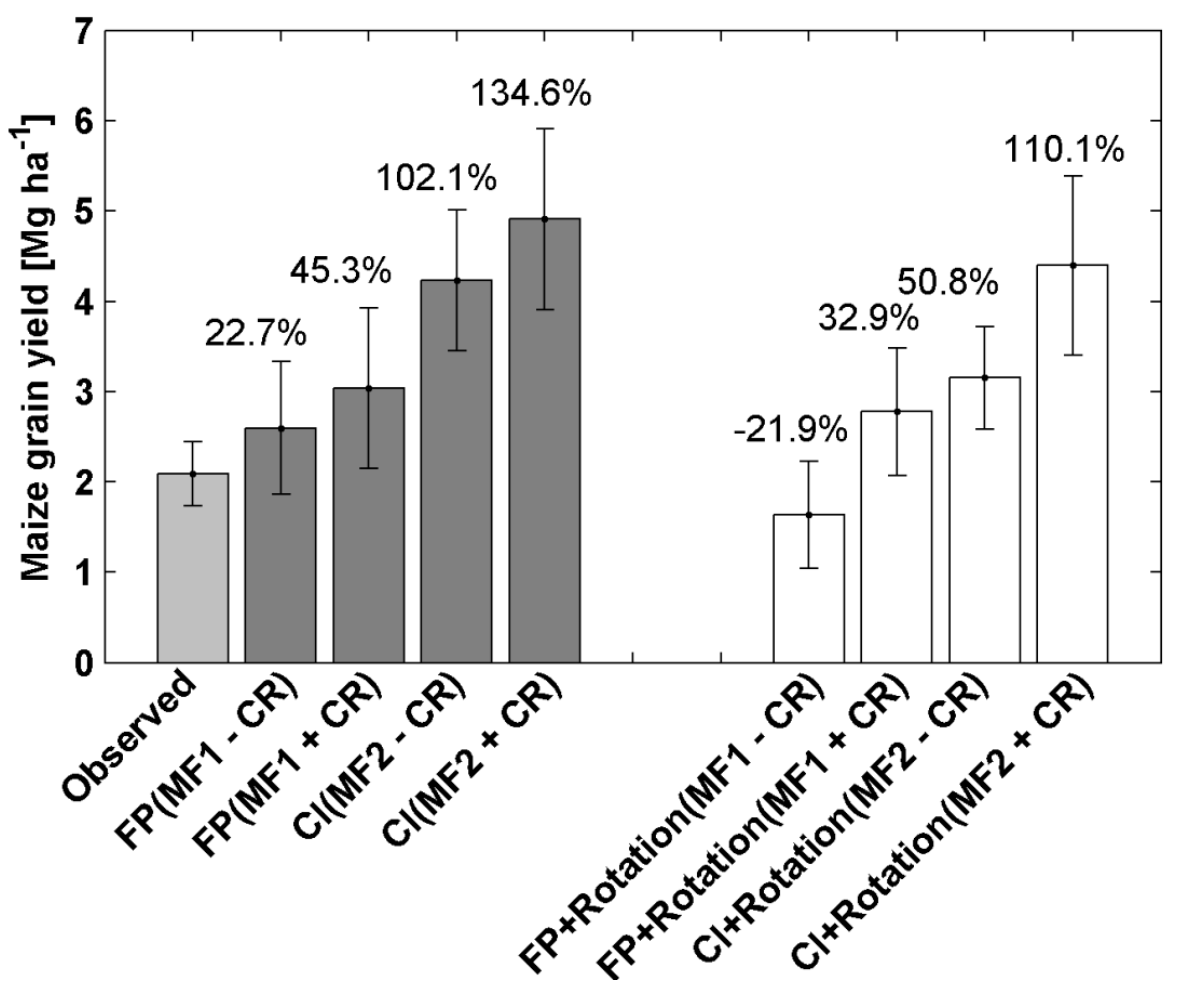

Figure 8. The Maize grain yield (in $\mathrm{Mg} \mathrm{ha}^{-1}$ ) under different intensification scenarios for maize production systems explored in Ethiopia: The bars are a standard deviation, and the numerical values placed above them are the percentage difference in Maize grain yield with the observed (farmer's yield) yield values. $\mathrm{FP}=$ Farmer's Practice; $\mathrm{CI}=$ Conventional Intensification; $\mathrm{MF} 1$ = current fertilizer rates; MF2 $=60 \mathrm{~kg} \mathrm{~N} \mathrm{ha}^{-1}+20 \mathrm{~kg} \mathrm{P} \mathrm{ha}^{-1} ; \mathrm{CR}=$ Crop Residue.

\subsection{Effect of Management Scenarios on Nitrogen Uptake}

There was a significant positive effect in the incorporation of crop residues and higher doses of mineral fertilizer application on nitrogen uptake by the plant $(p<0.005)$ in all the intensification scenarios explored in the current study (Figure 9). As expected, the highest Nitrogen uptake $\left(138.8 \mathrm{~kg} \mathrm{ha}^{-1}\right)$ was estimated in the conventional intensification where crop residues plus higher doses of mineral fertilizer $\left(60 \mathrm{~kg} \mathrm{~N} \mathrm{ha}^{-1}+20 \mathrm{~kg} \mathrm{P} \mathrm{ha}^{-1}+\mathrm{CR}\right)$ were applied in the field. The lowest nitrogen uptake $\left(40.5 \mathrm{~kg} \mathrm{ha}^{-1}\right)$ was estimated in the scenario where Groundnut was grown in rotation with Maize without incorporating the crop residues back in the field (FP + rotation-CR).

\subsection{Economic Profitability Calculations}

Based on the fact that the short rainy season comes first and then the long rainy seasons ("Belg" and "Meher" respectively) follow, the rotation scenario intends to introduce the cultivation of groundnut in the "Belg" season followed shortly by maize in the "Meher" season. The introduction of such a crop rotation within a single production year in non-irrigated areas could provide a number of agronomic advantages in addition to improving the soil fertility as a result of the nitrogen-fixing capacity of groundnut. It could also improve the income of farm households as a result of the production of groundnut as an additional crop.

In this section, the economic advantages of the crop rotation scenario are calculated in comparison with the conventional scenario. As clearly shown in Figure 8, the only difference between the two scenarios is the cultivation of groundnut in the minor or "Belg" season and the difference in the yield rate for maize. Since the scope of this paper is to identify the possible advantages of the rotation method over the conventional, it is appropriate to deal only with the profitability of groundnut production and market value of any yield difference in maize across corresponding simulations in the two scenarios. 
Based on data from the World Bank Ethiopian socioeconomic survey [38], groundnut production and transportation costs are calculated per hectare (see Table A1 in Appendix A for a detailed explanation). Since groundnut is currently produced in only a few areas in Ethiopia, the number of observations is low, which makes the calculation of these costs at the zone level difficult. The national average figures are calculated instead for all the variables needed here. The total production costs per hectare are calculated to be 6625.3 birr ("birr" is the basic monetary unit of Ethiopia), and the transportation cost is 472 birr based on the national average of 1.63 tons of output per hectare. Based on the price of 9160 birr per ton, the average yield results in a total farm sales revenue of 14,909.7 birr per hectare from groundnut production. This is calculated to be of 7812.4 birr gross economic profit (GEP) per hectare. (Note: Since land is usually rented for a minimum of a year, there is no need to consider land rental costs for groundnut cultivation within the crop rotation method.)

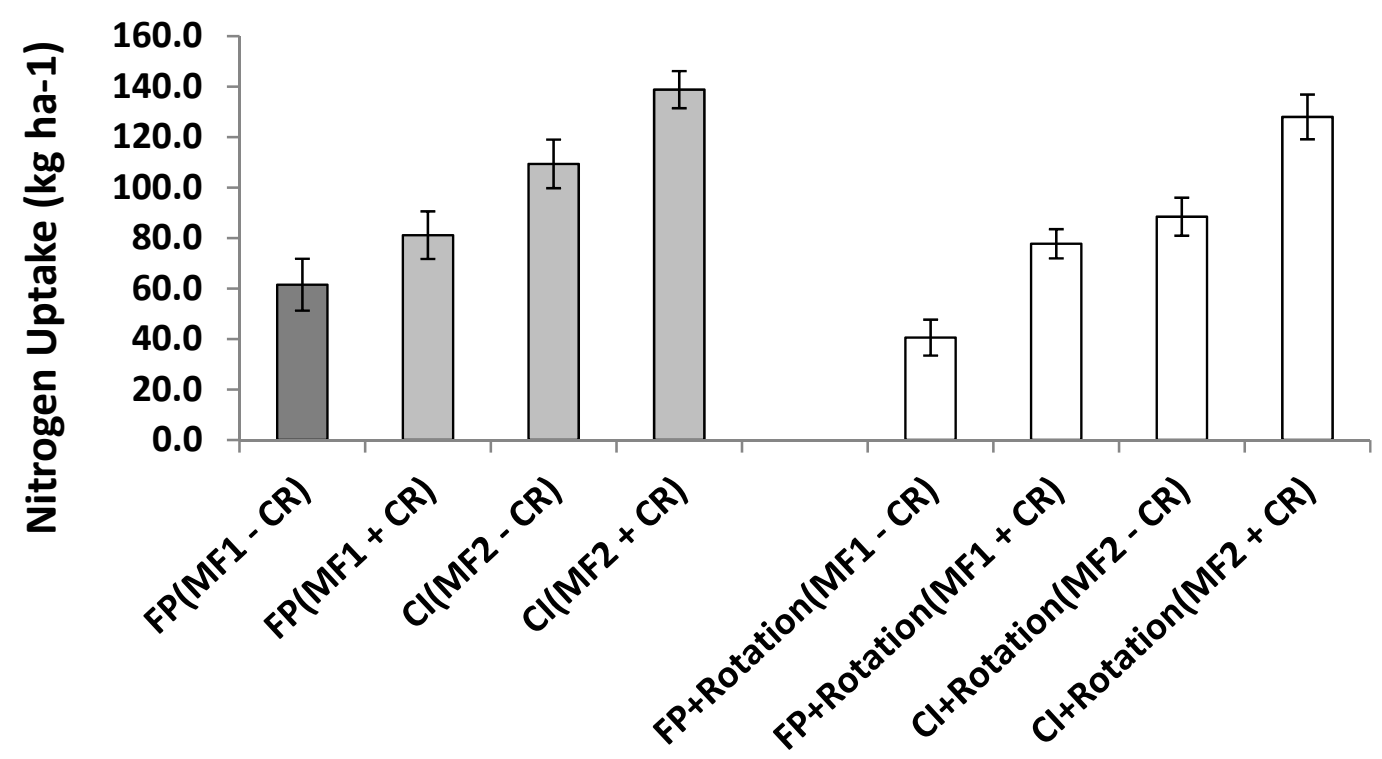

Figure 9. The nitrogen uptake (in $\mathrm{kg} \mathrm{ha}^{-1}$ ) under different intensification scenarios for maize production systems explored in Ethiopia: The bars are the values of standard deviation. FP = Farmer's Practice; $\mathrm{CI}=$ Conventional Intensification; MF1 = current fertilizer rates; $\mathrm{MF} 2=60 \mathrm{~kg} \mathrm{~N} \mathrm{ha}{ }^{-1}+20 \mathrm{~kg}$ $\mathrm{P} \mathrm{ha}^{-1} ; \mathrm{CR}=$ Crop Residue.

\section{Discussion}

The objective of this study was to quantify the long-term crop yield response and change in soil organic carbon and crop available $\mathrm{N}$ over time for conventional intensification with or without groundnut included in the rotation. Our results demonstrate that the value of crop available nitrogen in soil profiles have increased from $5 \mathrm{~kg} \mathrm{ha}^{-1}$ under current farmer's practices (i.e., FP, MF1-CR) to $30 \mathrm{~kg} \mathrm{ha}^{-1}$ under the rotation scenario (i.e., CI, MF2 + CR) including groundnut in the rotation (Figure 10). However, to take advantage of the benefits of groundnut on nitrogen availability to the maize crop, the release of $\mathrm{N}$ from above- and below-ground residues must be synchronous with maize $\mathrm{N}$ uptake.

Various researchers have reported the lower beneficial effect of crop rotation on maize yield with increasing $\mathrm{N}$ fertilization, especially when legumes were included $[39,40]$. In our study, the inclusion of groundnut as a rotation crop did result in a lower maize yield gain under higher fertilization compared to the yields under conventional intensification scenarios (Figure 8) despite the fact that the incorporation of legume $\mathrm{N}$, e.g., through the incorporation of groundnut biomass, led to large amounts of mineral $\mathrm{N}$ being available in the soil (Figure 11a). Compared with the cereals, legume residues are relatively rich in $\mathrm{N}$ with a lower $\mathrm{C}: \mathrm{N}$ ratio, and these characteristics favour the rapid decomposition and release of $\mathrm{N}$ to subsequent crops [11,41]. The reason for a lower maize yield when including 
groundnut in the rotation could be due to the mismatch of $\mathrm{N}$ release from groundnut residues and the development of maize roots and maize $\mathrm{N}$ demand. Thus, maize was not able to take advantage of the higher amount of crop available N (Figure 11a). In addition, groundnut consumes soil water during the short rainy season (belg) which can lead to less total crop available water over the rooting depth (CAWT) for the subsequent maize crop compared to the conventional intensification scenario without any crop in the short season (see Table A3 in Appendix A). The same findings were also reported in Western Kenya by Reference [42].

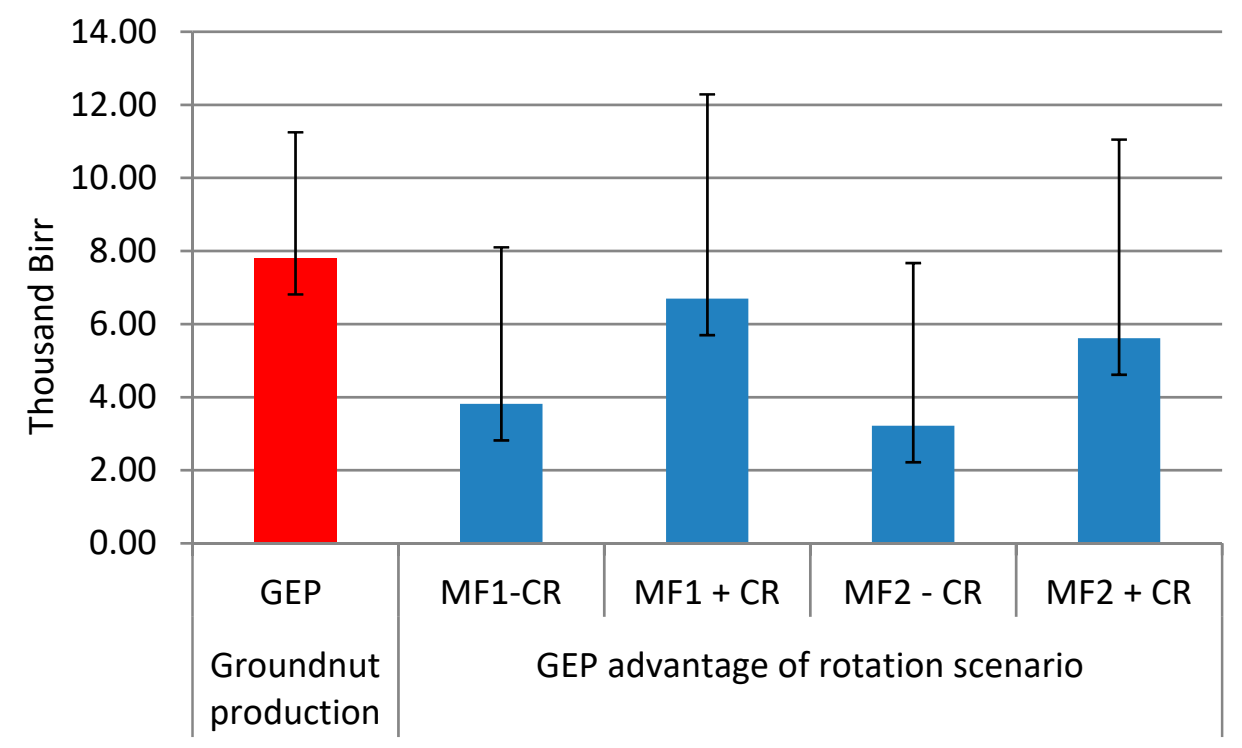

Figure 10. The average gross economic profit (GEP) $\left(\right.$ Birr ha $^{-1}$ year $^{-1}$ ) over Ethiopia from groundnut production and the average annual GEP advantage of rotation scenario over the conventional (in ‘000 Birr).

The observation of total organic carbon in the maize monoculture production system (i.e., conventional intensification) and legume-cereal rotation (Figure 11b) did not show a significant difference, which goes in accordance with the findings of earlier studies in SSA [43,44]. However, the plausible way through which the incorporation of grain legumes into the cereal-based system could enhance soil $\mathrm{C}$ contents is through the enhanced productivity of a subsequent cereal crop or through the intercropping systems with an enhanced total biomass production providing high-quality residues to enhance the buildup of soil organic matter [45]. Therefore, when compared to the respective conventional intensification scenario, the rotation scenarios have a slightly higher soil organic matter content.

Livestock is an important component of the farming systems in Ethiopia [46], and the use of maize and legume residues as feed is common. Residues of certain legumes, e.g., that of groundnut, are more likely to be removed for feed. The use of residues as feed creates a potential trade-off between the use of legume residues for soil fertility improvement or for feed [42]. In the latter case, the ability of the farmer to return manure from their livestock to their fields and to handle feed and manure well during storage and transport strongly affects the carryover rates of nutrients and carbon and the impacts on soil fertility [47]. 

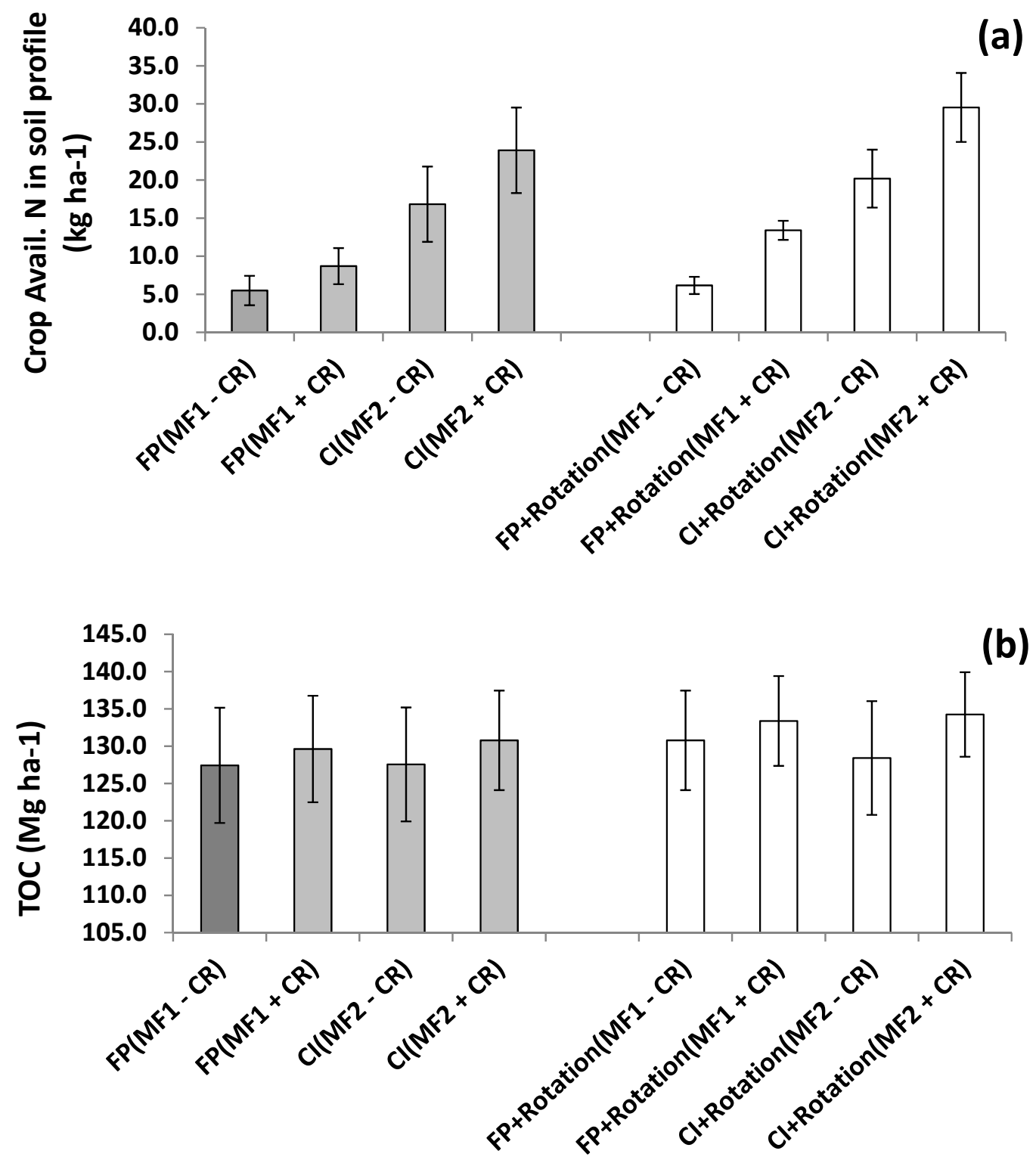

Figure 11. (a) The crop available Nitrogen in soil profile (in $\mathrm{kg} \mathrm{ha}^{-1}$ ) and (b) the Total Organic carbon (TOC; in $\mathrm{Mg} \mathrm{ha}^{-1}$ ) under different intensification scenarios for maize production systems explored in Ethiopia: The bars are the values of standard deviation. FP = Farmer's Practice; $\mathrm{CI}=$ Conventional Intensification; MF1 = current fertilizer rates; MF2 $=60 \mathrm{~kg} \mathrm{~N}^{-1}+20 \mathrm{~kg} \mathrm{P} \mathrm{ha}^{-1} ; \mathrm{CR}=$ Crop Residue.

Regarding the cost-benefit analysis with respect to the introduction of groundnut in rotation with maize, the results show that the inclusion of groundnut could be a profitable venture for farmers, although, averaged over Ethiopia, a rotation with groundnut has a negative impact on the maize yield (Figure 8). The blue bars in Figure 10 show the net GEP increase of the four rotation scenarios compared to the four scenarios without groundnut when averaged over the cropped area in the whole country. However, when looking at the administrative zone level results (Table 4 , the profitability of the rotation scenario has a large variation which is due to the variation in the calculated yield levels for groundnut. The very poor groundnut yield levels in zones like Asosa, Awi, Metekel, North and South Gonder, and West Gojam cannot compensate the loss of return from the reduced maize yields, leading to an overall lower economic return of the rotation system. Thus, the introduction of groundnut in crop rotation with maize in areas like these is disadvantageous, although the soil organic matter content may be slightly increased. However, in most of the zones in Ethiopia, the rotation scenarios have economic and ecological advantages. 
Table 4. The average annual Gross economic profit (GEP) advantage across Ethiopia (in 35 administrative zones) from groundnut production in rotation scenarios over the conventional (in '000 Birr).

\begin{tabular}{|c|c|c|c|c|}
\hline \multirow[b]{2}{*}{ Zone Name } & \multicolumn{4}{|c|}{ Rotation Scenarios } \\
\hline & MF1 - CR & MF1 + CR & MF2 - CR & MF2 + CR \\
\hline Alaba & 7.4 & 11.3 & 6.7 & 9.9 \\
\hline Asosa & -4.5 & -3.1 & -5.4 & -4.7 \\
\hline Awi & -2.5 & -0.4 & -3.9 & -0.9 \\
\hline Bale & 7.5 & 11.5 & 7.8 & 9.8 \\
\hline Basketo Special Woreda & 9.1 & 13.9 & 8.2 & 12.6 \\
\hline Benchi Maji & 7.9 & 12.9 & 7.2 & 11.3 \\
\hline Central Tigray & -1.0 & 0.5 & 1.8 & 3.2 \\
\hline East Gojam & 1.2 & 2.6 & 0.0 & 1.9 \\
\hline East Harerghe & 6.8 & 8.6 & 6.7 & 8.3 \\
\hline East Shewa & 2.4 & 4.2 & 0.4 & 0.8 \\
\hline East Wellega & 3.2 & 6.2 & 1.8 & 4.3 \\
\hline Gedeo & 9.8 & 16.2 & 9.4 & 15.0 \\
\hline Guraghe & 6.2 & 9.0 & 6.0 & 8.1 \\
\hline Hadiya & 7.6 & 12.3 & 6.8 & 10.5 \\
\hline Hundene & 0.9 & 0.9 & 0.9 & 0.7 \\
\hline Horo Guduru & 1.6 & 4.6 & 0.8 & 3.9 \\
\hline Illubabor & 6.1 & 10.2 & 4.9 & 8.3 \\
\hline Jimma & 8.9 & 13.8 & 7.7 & 12.5 \\
\hline Kelem Wellega & -0.3 & 1.7 & -2.0 & -1.4 \\
\hline Kemashi & 2.9 & 5.5 & 1.3 & 3.1 \\
\hline Kembata Alaba Tembaro & 9.1 & 13.5 & 8.3 & 12.2 \\
\hline Konta Special Woreda & 8.4 & 13.6 & 8.2 & 12.2 \\
\hline Metekel & -3.4 & -1.9 & -4.6 & -3.2 \\
\hline North Gonder & -3.9 & -2.8 & -4.2 & -3.1 \\
\hline Selti & 5.8 & 9.8 & 5.1 & 8.4 \\
\hline Sidama & 7.4 & 10.7 & 6.1 & 9.9 \\
\hline South Gonder & -1.5 & 0.2 & -2.1 & 0.0 \\
\hline South Omo & 7.4 & 11.8 & 8.9 & 11.9 \\
\hline South West Shewa & 5.3 & 7.4 & 4.8 & 6.0 \\
\hline Southern Tigray & 2.4 & 3.2 & 4.1 & 5.0 \\
\hline Arsi & 8.6 & 12.4 & 8.1 & 11.1 \\
\hline West Gojam & -1.8 & -0.4 & -3.1 & -1.0 \\
\hline West Harerghe & 3.2 & 5.3 & 2.6 & 3.3 \\
\hline West Shewa & 4.3 & 6.2 & 3.5 & 5.0 \\
\hline West Wellega & 1.1 & 3.3 & -0.4 & 1.6 \\
\hline
\end{tabular}

\section{Conclusions}

The conventional intensification option explored in the current study shows the positive effect of mineral fertilizer application and the incorporation of the crop residue back in the field. The incorporation of crop residue alone in the field can lead to an increase in maize yield by $45.3 \%$ compared to the farmer's yield under current mineral fertilizer application rates, whereas the crop residues combined with an increased amount of mineral fertilizer resulted in an increased yield of about $134.6 \%$. The same phenomenon was observed where Maize (in the long season) was grown in rotation with Groundnut (in the short season). The yields were increased by up to $110.1 \%$ depending upon the scenarios tested. However, in the scenario where crop residues were not incorporated in the field, the maize yield was reduced by $21.9 \%$. The cost-benefit analysis suggests that the incorporation of groundnut in maize-based systems could provide additional income to the farmers when averaged over Ethiopia; with some local exceptions in some administrative zones, the introduction of groundnut in the rotation turned out to be economically disadvantageous, although they slightly increased soil organic carbon over time compared to maize monoculture. 
Author Contributions: All authors substantially contributed to the conception, writing, and revisions of the paper. A.K.S. was the lead author.

Funding: The work was carried out under the project BiomassWeb within the GlobeE research programme. Funding by the Federal Ministry of Education and Research (BMBF) of Germany is highly acknowledged.

Acknowledgments: We are grateful to the anonymous reviewers for their valuable suggestions and comments which helped to improve the manuscript.

Conflicts of Interest: The authors declare no conflict of interest.

\section{Appendix A}

Table A1. The detailed calculations of the Gross economic profit for Ground Nut cultivation (Source: Authors' calculation based on data from the World Bank Ethiopia Socioeconomic Survey (ESS, 2014).)

\begin{tabular}{cc}
\hline Description & \\
\hline Production cost (Birr per ha) & 6625.26 \\
\hline Labor cost (Birr per ha) & 6093.7 \\
Wage rate (Birr per day) & 31.17 \\
Total labor day (per ha) & 195.5 \\
\hline Seed cost (Birr per ha) & 531.56 \\
Quantity of seed (Kg per ha) & 58.03 \\
Seed price (Birr per Kg) & 9.16 \\
\hline Fertilizer cost (Birr per ha) & 0 \\
Quantity Fertilizer (Kg per ha) & 0 \\
\hline Pesticide + herbicide cost (Birr per ha) & 0 \\
Quantity of pesticide + herbicide (Kg per ha) & 0 \\
\hline Total revenue (Birr per ha) & 14909.732 \\
Price (Birr per Mg) & 9160 \\
Quantity of output (Mg per ha) & 1.628 \\
\hline Total transportation cost (Birr per ha) & 472.12 \\
Quantity of output (Mg per ha) & 1.6277 \\
Transportation cost (Birr per Mg) & 290 \\
\hline Gross economic profit (GEP) (Birr per ha) & 7812.35 \\
\hline
\end{tabular}

Table A2. The sand, silt, clay, and organic carbon (OC) content used as an input for the model calibration at Jimma (in Ethiopia) and Bambey and Niori (in Senegal).

\begin{tabular}{cccccc}
\hline Sites & Depth $(\mathbf{c m})$ & OC (\%) & Sand $(\mathbf{\%})$ & Silt $\mathbf{( \% )}$ & Clay $\mathbf{( \% )}$ \\
\hline \multirow{6}{*}{ Jimma } & $0-5$ & 2.0 & 30.0 & 31.0 & 39.0 \\
& $5-40$ & 1.5 & 15.5 & 14.5 & 71.0 \\
& $40-70$ & 1.0 & 15.0 & 9.0 & 76.0 \\
& $70-110$ & 0.8 & 15.0 & 6.5 & 78.0 \\
& $110-200$ & 0.6 & 17.5 & 6.5 & 76.0 \\
\hline \multirow{6}{*}{ Bambey } & $0-10$ & 0.2 & 95.0 & 1.5 & 2.8 \\
& $10-20$ & 0.1 & 92.7 & 1.7 & 3.8 \\
& $20-30$ & 0.1 & 91.8 & 1.6 & 5.1 \\
& $30-40$ & 0.2 & 91.2 & 1.7 & 6.2 \\
& $40-50$ & 0.3 & 89.9 & 1.8 & 7.0 \\
& $50-60$ & 0.1 & 89.7 & 1.7 & 7.2 \\
& $60-70$ & 0.1 & 91.5 & 2.2 & 6.5 \\
& $70-80$ & 0.1 & 91.1 & 2.6 & 6.2 \\
& $80-90$ & 0.1 & 90.4 & 2.0 & 6.1 \\
& $90-100$ & 0.1 & 87.6 & 1.3 & 5.9 \\
\hline
\end{tabular}


Table A2. Cont.

\begin{tabular}{cccccc}
\hline Sites & Depth $(\mathbf{c m})$ & OC (\%) & Sand (\%) & Silt $\mathbf{( \% )}$ & Clay (\%) \\
\hline \multirow{6}{*}{ Nioro } & $0-10$ & 0.5 & 92.8 & 4.3 & 4.5 \\
& $10-20$ & 0.4 & 88.7 & 9.7 & 3.2 \\
& $20-30$ & 0.4 & 86.5 & 10.3 & 3.4 \\
& $30-40$ & 0.4 & 86.6 & 9.2 & 3.1 \\
& $40-50$ & 0.3 & 84.3 & 12.0 & 4.0 \\
& $50-60$ & 0.2 & 80.7 & 13.9 & 4.6 \\
& $60-70$ & 0.2 & 77.6 & 3.6 & 18.4 \\
& $70-80$ & 0.2 & 74.0 & 4.1 & 21.4 \\
& $80-90$ & 0.2 & 73.1 & 11.0 & 14.8 \\
& $90-100$ & 0.2 & 72.5 & 4.3 & 23.9 \\
\hline
\end{tabular}

Table A3. The total crop available water over the actual rooting depth (CAWT) in mm under different intensification scenarios for the maize production systems explored in Ethiopia. Abbreviations: $\mathrm{FP}=$ Farmer's Practice; $\mathrm{CI}=$ Conventional Intensification; $\mathrm{MF} 1=$ current fertilizer rates; $\mathrm{MF} 2=60 \mathrm{~kg} \mathrm{~N} \mathrm{ha}^{-1}+20 \mathrm{~kg} \mathrm{P} \mathrm{ha}^{-1} ; \mathrm{CR}=$ Crop Residue.

\begin{tabular}{lcccccccc}
\hline & \multicolumn{2}{c}{ FP } & \multicolumn{2}{c}{ CI } & \multicolumn{2}{c}{ FP + Rotation } & \multicolumn{2}{c}{ CI + Rotation } \\
\cline { 2 - 10 } & MF1 - CR & MF1 + CR & MF2 - CR & MF2 + CR & MF1 - CR & MF1 + CR & MF2 - CR & MF2 + CR \\
\hline CAWT $(\mathrm{mm})$ & 23.7 & 26.0 & 31.7 & 33.6 & 14.3 & 20.6 & 22.3 & 25.6 \\
\hline
\end{tabular}

\section{References}

1. Van Ittersum, M.K.; van Bussel, L.G.J.; Wolf, J.; Grassini, P.; van Wart, J.; Guilpart, N.; Claessens, L.; de Groot, H.; Wiebe, K.; Mason-D'Croz, D.; et al. Can sub-Saharan Africa feed itself? Proc. Natl. Acad. Sci. USA 2016, 113, 14964-14969. [CrossRef] [PubMed]

2. Folberth, C.; Yang, H.; Gaiser, T.; Abbaspour, K.C.; Schulin, R. Modeling maize yield responses to improvement in nutrient, water and cultivar inputs in sub-Saharan Africa. Agric. Syst. 2013, 119, $22-34$. [CrossRef]

3. Akinnifesi, F.K.; Ajayi, O.C.; Sileshi, G.; Chirwa, P.W.; Chianu, J. Fertiliser trees for sustainable food security in the maize-based production systems of East and Southern Africa. A review. Agron. Sustain. Dev. 2010, 30, 615-629. [CrossRef]

4. Sanginga, N. Role of biological nitrogen fixation in legume based cropping systems; a case study of West Africa farming systems. Plant Soil 2003, 252, 25-39. [CrossRef]

5. Van Oort, P.A.J.; Saito, K.; Tanaka, A.; Assagba-Amovin, E.; Van Bussel, L.G.J.; van Wart, J.; de Groot, H.; van Ittersum, M.K.; Cassman, K.G.; Wopereis, M.C.S. Assessment of rice-sufficiency in 2025 in eight African countries. Glob. Food Secur. 2015, 5, 39-49. [CrossRef]

6. Hall, A.J.; Richards, R.A. Prognosis for genetic improvement of yield potential and water-limited yield of major grain crops. Field Crop Res. 2013, 143, 18-33. [CrossRef]

7. Bouwman, L.; Goldewijk, K.K.; van Der Hoek, K.W.; Beusen, A.H.W.; van Vuuren, D.P.; Willems, J.; Rufino, M.C.; Stehfest, E. Exploring global changes in nitrogen and phosphorus cycles in agriculture induced b livestock production over the 1900-2050 period. Proc. Natl. Acad. Sci. USA 2013, 110, 20882-20887. [CrossRef]

8. Vanlauwe, B.; Bationo, A.; Chianu, J.; Giller, K.E.; Merckx, R.; Mokwunye, U.; Ohiokpehai, O.; Pypers, P.; Tabo, R.; Shepherd, K.; et al. Integrated soil fertility management: Operational definition and consequences for implementation and dissemination. Outlook Agric. 2010, 39, 17-24. [CrossRef]

9. Reckling, M.; Hecker, J.-M.; Bergkvist, G.; Watson, C.; Zander, P.; Stoddard, F. A cropping system assessment framework-Evaluating effects of introducing legumes into crop rotations. Eur. J. Agron. 2016, 76, 186-197. [CrossRef]

10. Chen, X.; Cui, Z.; Fan, M.; Vitousek, P.; Zhao, M.; Ma, W.; Wang, Z.; Zhang, W.; Yan, X.; Yang, J. Producing more grain with lower environmental costs. Nature 2014, 514, 486-489. [CrossRef] [PubMed] 
11. Franke, A.C.; van den Brand, G.J.; Vanlauwe, B.; Giller, K.E. Sustainable intensification through rotations with grain legumes in Sub-Saharan Africa: A review. Agric. Ecosyst. Environ. 2018, 261, 172-185. [CrossRef] [PubMed]

12. Crawford, E.W.; Jayne, T.S.; Kelly, V.A. Alternative Approaches for Promoting Fertilizer Use in Africa. In Agriculture and Rural Development Discussion Paper 22; The World Bank: Washington, DC, USA, 2006.

13. Sanchez, P. Tripling crop yields in tropical Africa. Nat. Geosci. 2010, 3, 299-300. [CrossRef]

14. Palm, C.A.; Smukler, S.M.; Sullivan, C.C.; Mutuo, P.K.; Nyadzia, G.I.; Walsh, M.G. Identifying potential synergies and trade-offs for meeting food security and climate change objectives in Sub-Saharan Africa. Proc. Natl. Acad. Sci. USA 2010, 107, 19661-19666. [CrossRef] [PubMed]

15. World Bank Group. Available online: https://data.worldbank.org/indicator/AG.LND.ARBL.ZS?view= chart (accessed on 20 March 2019).

16. Regassa, S.; Givey, C.; Castillo, G.E. The Rain Doesn't Come on Time Anymore: Poverty, Vulnerability, and Climate Variability in Ethiopia. Oxfam Policy Pract. 2010, 6, 90-134.

17. Srivastava, A.K.; Mboh, C.M.; Gaiser, T.; Zhao, G.; Ewert, F. Climate change impact under alternate realizations of climate scenarios on maize yield and biomass in Ghana. Agric. Syst. 2017. [CrossRef]

18. Trawally, D.; Webber, H.; Agyare, W.A.; Fosu, M.; Naab, J.; Gaiser, T. Effect of heat stress on two maize varieties under irrigation in Northern Region of Ghana. Int. J. Biol. Chem. Sci. 2015, 9, 1571-1587.

19. Eyshi Rezaei, E.; Siebert, S.; Ewert, F. Impact of data resolution on heat and drought stress simulated for winter wheat in Germany. Eur. J. Agron. 2015, 65, 69-82. [CrossRef]

20. Zhao, G.; Webber, H.; Hoffmann, H.; Wolf, J.; Siebert, S.; Ewert, F. The implication of irrigation in climate change impact assessment: A European wide study. Glob. Chang. Biol. 2015, 21, 4031-4048. [CrossRef] [PubMed]

21. Faye, B.; Webber, H.; Diop, M.; Mbaye, M.; Owusu-Sekyere, J.D.; Naab, J.B.; Gaiser, T. Potential impact of climate change on peanut yield in Senegal, West Africa. Field Crops Res. 2018, 219, 148-159. [CrossRef]

22. Yin, X.G.; Kersebaum, K.C.; Kollas, C.; Manevski, K.; Baby, S.; Beaudoin, N.; Ozturk, I.; Gaiser, T.; Wu, L.H.; Hoffmann, M.; et al. Performance of process-based models for simulation of grain $\mathrm{N}$ in crop rotations across Europe. Agric. Syst. 2017, 154, 63-77. [CrossRef]

23. Kollas, C.; Kersebaum, K.C.; Nendel, C.; Manevski, K.; Nüller, C.; Palosuo, T.; Armas-Herrera, C.M.; Beaudoin, N.; Bindi, M.; Charfeddine, M.; et al. Crop rotation modelling-A European model intercomparison. Eur. J. Agron. 2015, 70, 98-111. [CrossRef]

24. Wolf, J. User Guide for LINTUL5: Simple Generic Model for Simulation of Crop Growth under Potential, Water Limited and Nitrogen, Phosphorus and Potassium Limited Conditions; Wageningen University: Wageningen, The Netherlands, 2012; pp. 1-63.

25. Allen, R.G.; Pereira, L.S.; Raes, D.; Smith, M. Crop Evapotranspiration: Guidelines for Computing Crop Water Requirements; Irrigation \& Drainage Paper 56; FAO: Rome, Italy, 1998; p. 301.

26. Corbeels, M.; Mcmurtrie, R.E.; Pepper, D.; O'Connell, A.M. A process-based model of nitrogen cycling in forest plantations: Part I. Structure, calibration and analysis of the decomposition model. Ecol. Model. 2015, 187, 426-448. [CrossRef]

27. Jaleta, M.; Yirga, C.; Kassie, M.; de Groote, H.; Shiferaw, B. Knowledge, Adoption and Use Intensity of Improved Maize Technologies in Ethiopia. In Proceedings of the 4th International Conference of the African Association of Agricultural Economists, Hammamet, Tunisia, 22-25 September 2013.

28. Faye, B.; Webber, H.; Gaiser, T.; Diop, M.; Owusu-Sekyere, J.D.; Naab, J.B. Effects of fertilization rate and water availability on peanut growth and yield in Senegal (West Africa). J. Sustain. Dev. 2016, 9, 111-131. [CrossRef]

29. Boote, K.J. Growth stages of peanut (Arachis hypogaea L.). Peanut Sci. 1982, 9, 35-49. [CrossRef]

30. Meier, U. (Ed.) Stades Phénologiques des mono-et Dicotylédones Cultivées BBCH Monographie, 2nd ed. Available online: http://www.iki.bund.de/fileadmin/damuploads/veroeff/bbch/BBCH-Skala_franz\% C3\%B6sisch. (accessed on 20 March 2019).

31. Papula, A. Mathematik fur Chemiker, 2nd ed.; Enke-Verlag: Stuttgart, Germany, 1982; p. 405.

32. Ruane, A.C.; Goldberg, R.; Chryssanthacopoulos, J. AgMIP climate forcing datasets for agricultural modeling: Merged products for gap-filling and historical climate series estimation. Agric. For. Meteorol. 2015, 200, 233-248. [CrossRef] 
33. Rienecker, M.M.; Suarez, M.J.; Gelaro, R.; Todling, R.; Bacmeister, J.; Liu, E.; Bosilovich, M.G.; Schubert, S.D.; Takacs, L.; Kim, G.K.; et al. MERRA: NASA's Modern-Era Retrospective Analysis for Research and Applications. J. Clim. 2011, 24, 3624-3648. [CrossRef]

34. Saha, S.; Moorthi, S.; Pan, H.L.; Wu, X.; Wang, J.; Nadiga, S.; Tripp, P.; Kistler, R.; Woollen, J.; Behringer, D.; et al. The NCEP Climate Forecast System Reanalysis. Bull. Am. Meteorol. Soc. 2010, 91, 1015-1057. [CrossRef]

35. Rawls, W.J.; Ahuja, L.R.; Maidment, D.R. Handbook of Hydrology; McGraw-Hill: New York, NY, USA, 1993; p. 1442.

36. Chala, A.; Mohammed, A.; Ayalew, A.; Skinnes, H. Natural occurrence of aflatoxins in groundnut (Arachis hypogaea L.) from eastern Ethiopia. Food Control 2013, 30, 602-605. [CrossRef]

37. Smart, M.G.; Shotwell, O.L.; Caldwell, R.W. Pathogenesis in Aspergillus ear rot of maize: Aflatoxin B1 levels in grains around wound inoculation sites. Phytopatology 1994, 80, 1283-1286. [CrossRef]

38. Ethiopia Socioeconomic Survey (ESS). World Bank Ethiopia Socioeconomic Survey; ESS: Addis Ababa, Ethiopia, 2014.

39. Nevens, F.; Reheul, D. Crop rotation versus monoculture; yield, $\mathrm{N}$ yield and ear fraction of silage maize at different levels of mineral $\mathrm{N}$ fertilization. Wagening. J. Life Sci. 2001, 49, 405-425. [CrossRef]

40. Riedell, W.E.; Schumacher, T.E.; Clay, S.A.; Ellsbury, M.M.; Pravecek, M.; Evenson, P.O. Cornand soil fertility responses to crop rotation with low, medium or high inputs. Crop Sci. 1998, 38, 427-433. [CrossRef]

41. Anyanzwa, H.; Okalebo, J.R.; Othieno, C.O.; Bationo, A.; Waswa, B.S.; Kihara, J. Effects of conservation tillage, crop residue and cropping systems on changes in soil organic matter and maize-legume production: A case study in Teso District. Nutr. Cycl. Agroecosyst. 2010, 88, 39-47. [CrossRef]

42. Ojiem, J.O.; Franke, A.C.; Vanlauwe, B.; de Ridder, N.; Giller, K.E. Benefits of legume-maize rotations: Assessing the impact of diversity on the productivity of smallholders in Western Kenya. Field Crops Res. 2014, 168, 75-85. [CrossRef]

43. Franke, A.C.; Berkhout, E.D.; Iwuafor, E.N.O.; Nziguheba, G.; Dercon, G.; Vandeplas, I.; Diels, J. Does crop-livestock integration lead to improved crop productivity in the savanna of West Africa? Exp. Agric. 2010, 46, 439-455. [CrossRef]

44. Bationo, A.; Ntare, B.R. Rotation and nitrogen fertilizer effects on pearl millet, cowpea and groundnut yield and soil chemical properties in a sandy soil in the semi-arid tropics, West Africa. J. Agric. Sci. 2000, 134, 277-284. [CrossRef]

45. Samake, O.; Stomph, T.J.; Kropff, M.J.; Smaling, E.M.A. Integrated pearl millet management in the Sahel: Effects of legume rotation and fallow management on productivity and Striga hermonthica infestation. Plant Soil 2006, 286, 245-257. [CrossRef]

46. Birara, E.; Zemen, A. Assessment of the Role of Livestock in Ethiopia: A Review. Am. Eurasian J. Sci. Res. 2016, 11, 405-410.

47. Rufino, M.C.; Rowe, E.C.; Delve, R.J.; Giller, K.E. Nitrogen cycling efficiencies through resource-poor African crop-livestock systems. Agric. Ecosyst. Environ. 2006, 112, 261-282. [CrossRef] 